\title{
The Text of Goodf and John Donne's Itinerary in April 1613
}

\author{
Margaret Maurer and Dennis Flynn
}

\begin{abstract}
Two manuscript copies of John Donne's poem entitled in the first edition of his poems "Goodfriday, 1613. Riding Westward" came to light in the 1970s, both in the hand of Nathaniel Rich, an acquaintance of Donne and a member of a family with whom Donne had other connections. This essay expands on early analysis of these manuscripts to argue for their importance. The versions of the poem they convey are coherent and substantially different from its received text, and geographical indications in their headings are compatible with a 1613 journey Donne may have made in the company of Rich himself or someone Rich knew. In relation to the canonical version of Donne's poem, these two manuscripts seem to record a revising mind at work, possibly Rich's, conceivably that of Donne himself.
\end{abstract}

\section{Do} ONNE'S VERSE MEDITATION GOODF has PROVOCATIVE BIOGRAPHical associations. ${ }^{1}$ Its speaker is making a westward journey on Good Friday, a direction he tells us is opposite to what his soul's intelligence, devotion, dictates. Several manuscript texts of the poem, along with other poems and letters Donne wrote during the same period, attest that Donne himself made such a journey, riding from London to Montgomery, Wales, in the spring of 1613, about twenty months before he took orders as a priest in the Church of England. When two manuscript versions of the poem came to light in the 1970s, initial commentary on them suggested that they may be independent from and antecedent to what recent editors have assumed is the sole authorial version of the poem. Newly assembled biographical and historical details support reconsidering this possibility.

1. On the biographical implications of Goodf, see Guibbory 2011, 677, and SH Am I 2011, 523-36. Short titles of Donne's poems in this essay are those used in The Variorum Edition of the Poetry of John Donne. References here to manuscripts of Donne's poems likewise employ Variorum sigla. 
In a 2002 essay, Gary Stringer, general editor of The Variorum Edition of the Poetry of John Donne, described four criteria he uses "to evaluate a given variant's claim to [authorial] authenticity". Two of them are local to the variant word or phrase: it must be a "genuine alternative" (the phrase is Helen Gardner's, in Stringer's words, "used to describe certain powerfully appealing readings that she is not willing to set down as 'revisions"') ${ }^{2}$ and not "readily explicable as a scribal misreading or slip of the pen". A third depends on a systematic account of the relationships of all the witnesses to one another: the variant must be "appropriately located in the poem's transmissional history". The fourth criterion takes into account biographical and historical details, "touching individual scribes, artifacts, or transcriptions that affect confidence in the legitimacy of particular readings" (STRINGER 2002, 134). ${ }^{3}$

All of these criteria are addressed in this essay; but, of the four, it is the identity of the scribe that most immediately and provocatively justifies attention to these versions of the poem. Conveying a significantly different Goodf from the poem's received text, these manuscripts record either its concerted reconception by a scribe contemporary to Donne and interested in his poetry or earlier stages of the poem's argument articulated by Donne himself. In either case, they illuminate a crucial element of the argument of Goodf in its well-known form.

2. In her two editions of Donne's Divine Poems, Gardner does seem shy of the word revision, though she does not entirely avoid it. Of Lit, she wrote in 1952, "In these five [Group III] MSS. there are a few readings which may go back to an earlier state of the text than that preserved in Group I and II [. . . . If Donne did revise this poem, his revisions were trivial". This became, in the second edition of 1978, "The number of plausible readings common to the Group III manuscripts suggests they may preserve an earlier version. But, if Donne did revise this poem, his revisions were trivial". Of Annun, she wrote in 1952 and did not change in 1978, "There are some Group III readings which seem likely to have stood in Donne's first version". And of Goodf she wrote in 1952, "The fact that in this poem there are no 'Group III readings' strengthens the case for regarding these readings when they do occur as genuine alternative readings going back to a different version of the poem". In 1978, she eliminated the phrase Stringer quoted: "The absence of 'Group III readings' here strengthens the case for regarding them when they do occur as derived from a different version of the poem" (GARDNER 1952 and 1978, 80, 95, 98).

3. An excerpt from this essay is Appendix 2 in Stringer et al. 2005, 7.1:111-2. 


\section{Identification of the Scribe and Early Bibliographical Analysis}

Goodf is witnessed in the 1633 and later editions of Poems by J. D. and in several manuscripts of Groups I, II, and III, all these texts, according to Gardner, descending from the same lost holograph. ${ }^{4}$ The two most recently discovered manuscripts, however, P2 (Appendix A) and PT2 (Appendix B), whose close relationship has never been fully explored, stand distinctly apart from all the other manuscript copies of the poem and all the early editions. (See major variants of P2 and PT2 from Gardner's text in Appendix C, pp. 88-90.)

In 1974, R. S. Thomson and David McKitterick announced discovery of $\mathrm{P} 2$ at the Huntingdonshire Archives among papers of the Dukes of Manchester, the same collection that had once also included the only extant holograph of a Donne poem, the verse letter Carey, addressed to Lettice (Rich) Cary from Amiens in 1612 (Thomson and McKitterick 1974, 870). ${ }^{5}$ At first under the mistaken impression that P2 as well was a Donne holograph, "Donne's own copy of a poem he later developed", Thomson and McKitterick in a later letter to the editor of TLS allowed "some doubt" that P2 was in Donne's hand, having been supplied by Theo-

4. See Gardner 1978, lxxxi-lxxxvii, for her summary of her "theory of the transmission of the Divine Poems in manuscript" and her discussion of the texts of 1633 Poems in relation to the manuscripts.

5. The holograph verse letter is now at Oxford's Bodleian Library, MS Eng. poet. d. 197. Its early provenance may be explained by the fact that it had become part of the estate of Edward Montagu (1602-1671), Viscount Mandeville, later created second Earl of Manchester, when the widow Essex (Cheke) Bevill became his third wife in February 1642. She was the daughter of Essex (Rich) Cheke, conspicuously alluded to as the sister of the addressee in 11. 51-60 of Carey and, in the 1633 edition and several early manuscript headings, named along with her elder sister Lettice (Rich) Cary as joint addressees of that poem. For images of the holograph with a bibliographical description, see Digital Donne.

The presence of P2 and PT2 among the papers of the Dukes of Manchester may be explained by the fact that the scribe, Nathaniel Rich, had appointed Viscount Mandeville executor of his estate before his death in 1636. The Manchester papers were held by the Historical Manuscripts Commission at the Public Record Office beginning in 1882, until Sotheby's dispersed them in a series of auction sales. The holograph Carey and PT2 were both sold on 23 June 1970 (lots 267 and 268 respectively); see Historical Manuscripts Commission 1979, 3ff.; KeEn 1970, 2; and Croft 1970, 106-8. 
dore Hofmann with a photograph of PT2. This was another, somewhat different copy of Goodf in the same hand as P2, originally held among the Manchester papers but purchased by Hofmann at the Sotheby's auction on 23 June 1970. Thomson and McKitterick subsequently acknowledged that, in the auction catalogue, Sotheby's manuscripts expert P. J. Croft had described PT2 as a "contemporary manuscript" penned by someone other than Donne $(1974,930){ }^{6}$

In the auction catalogue, as Thomson and McKitterick came belatedly to know, Croft had written further concerning PT2 a passage that, as the first scholarly discussion of either manuscript, warrants attention here:

The present manuscript is of textual interest, for it contains variant readings not recorded in the latest scholarly edition (The Divine Poems, ed. Helen Gardner, Oxford, 1952, pp. 30-31 and 98-100), some of which may belong to an early version which Donne was subsequently to revise. Thus lines 33-6 read here:

These things as thus I ryde are from myne Eye

Yett are they present to my Memorye

That lookes on them, and thou lookest towards me

Deare Saviour as thou hangst uppon that Tree:

while in Gardner's text they read,

Though these things, as I ride, be from mine eye,

They'are present yet unto my memory,

For that looks towards them; and thou looks't towards mee,

O Saviour, as thou hang'st upon the tree.

Lines 17-18 of the published text are not present in this manuscript (and may therefore have been added at a later revision), and lines 5-6 were subsequently interlined by the same scribe (line 5 being here in an unrecorded variant version). $(1970,108)$

Significant in particular is Croft's noting in PT2 the absence of a couplet that appeared in the 1633 edition (11. 17-8). Croft did not specify that this couplet might have been omitted during the transcribing of PT2 but

6. Hofmann himself later wrote a letter stating that PT2 "is definitely not in Donne's hand". 
instead conjectured that it "may [. . . ] have been added" to the poem "at a later revision" in the manuscript tradition leading to the published text. He thus proposed in effect that PT2 may descend from a lost original holograph antecedent in the manuscript tradition to the version of the poem Helen Gardner had published in 1952. Gardner correctly perceived that all then available witnesses descended from the same holograph; but Croft wrote about the newly discovered PT2 that it may date from a time before Donne completed the poem Gardner knew.

Like Croft's suggestion about PT2, the view of Thomson and McKitterick about $\mathrm{P} 2$ was that it might represent a version of the poem earlier than the 42-line version Gardner published, using as her copy-text the 1633 edition. They cited twenty-nine variants of P2 from the text of 1633 , several of which they regarded as authorial. In particular, they pointed to 11. 9-10: "Hence is'it that I trauayle vnto the West / This day, when my Soules forme tends vnto the East". Noting in the word trauayle a "dual meaning of toil and travel, which so aptly reflects Donne's state", they contrasted this reading to the version in the manuscript Groups and early editions: "Hence is't, that I am carryed towards the West / This day, when my Soules forme bends toward the East", observing that trauayle was "one of many readings abandoned in later versions". Another variant they suggested might be authorial was P2's "Scoure of my rust" in 1. 36, reading against "Burne off my rusts" in 1.40 of the text in 1633; to Thomson and McKitterick it seemed "arguable" that Scoure is actually a "better reading" than Burne, and that like trauayle it might well therefore have been Donne's first thought later revised. Of course, at that point Thomson and McKitterick also proposed that P2 is an original holograph distinct in the manuscript tradition from the version of the manuscript Groups and early editions, which they thought were products of Donne's revision; however, when they later conceded that P2 may not be in Donne's hand, this argument lost much of its bibliographical force.

Thomson and McKitterick further observed that "the most significant" revision of P2 occurring in the 42-line version of the manuscript Groups and early editions was what they called "the addition of four lines inserted" after 1. 16. P2 reads,

Yett am I allmost glad, I did not see

That spectacle, of too much weight for me!

Could I behould those hands that spann the Poles, And tune all Sphæres at once, peir'ced through $\mathrm{w}^{\text {th }}$ holes? 
whereas Gardner's 1633-based text, substantially following the manuscript Groups, contains two additional couplets:

Yet dare I'almost be glad, I do not see

That spectacle of too much weight for mee.

Who sees Gods face, that is selfe life, must dye;

What a death were it then to see God dye?

It made his owne Lieutenant Nature shrinke,

It made his footstoole crack, and the Sunne winke.

Could I behold those hands which span the Poles,

And tune all spheares at once, peirc'd with those holes?

Although they made no further analysis of this comparison, Thomson and McKitterick did not think the four lines had been carelessly omitted by the scribe of P2. Independently, they were inclined to think as Croft did about PT2 that the absence of lines in P2 resulted not from faulty transcription but from "extensive re-working" of the text between the composition of the P2 version and the version printed in 1633.

Nicolas Barker then published an image of PT2 in TLS, commenting on both manuscripts and opening his rejoinder to Thomson and McKitterick by devoting considerable attention to the handwriting of P2 (1974, 996-7). ${ }^{7}$ Although he could not himself identify the scribal hand, he stated decisively that it "cannot be Donne's autograph". The certainty with which Barker prosecuted this argument makes his respect for the form of the poem in both P2 and PT2 particularly worthy of note. He did not yet know who the scribe was; but he did not assume that the judgment of Thomson and McKitterick that P2 readings were authorial could be tied merely to the mistaken belief that P2 was in Donne's hand. Certain that it was not, Barker (like Croft and like Thomson and McKitterick) not only did not think P2 and PT2 were corrupt copies in the tradition of the manuscript Groups but was also sufficiently impressed with the form of the poem in P2 and PT2 that, having "puzzled over the relation of [the] variants between the two manuscripts", he undertook, if briefly, the only serious analysis of these two manuscripts to date.

He began by observing that in both P2 and PT2 the headings seem "to have been added as an afterthought". Although he did not specify evidence

7. In his discussion of the handwriting of P2, Barker relied on Croft's analysis of Donne's hand (Croft 1973, 1:25-6), and also quoted from Croft's 1970 discussion of PT2. 
for this perception, he went on to contrast the two headings: "meditation vpon a Good friday, ryding from London towards Exceter, westward" (P2) and "Meditation on a good friday ridinge from London into $y^{\mathrm{e}}$ West Countrey" (PT2). He alluded to a point made by Thomson and McKitterick, that the P2 heading, with its reference to a journey "towards Exceter", has "prompted the speculation that the poem was written about a different occasion from that usually supposed" (BARKER 1974, 997), ${ }^{8}$ that is, an occasion when the speaker was riding "from London" towards Exeter rather than (as may be deduced from several headings of the manuscript Groups and early editions) from some unnamed place towards Montgomery. Barker assumed that the heading of PT2, referring to a ride "from London into $y^{\mathrm{e}}$ West Countrey", more than the heading in P2, is compatible with the various headings of manuscript Groups and early editions and thus may be a scribal correction of the $\mathrm{P} 2$ heading.

Barker was, however, wrong about this. Like reference to Exeter, reference to "the West Countrey" is specifically to the west counties of England, excluding Wales. ${ }^{9}$ Thus one must question both Barker's observation that the heading of PT2 corrects a mistake in the heading of P2 and the consequent conclusion he draws that this change makes it "unlikely that the scribe had special information on the occasion of the poem". PT2 slightly generalizes rather than corrects P2 by stating that the speaker of Goodf composed his meditation as he was riding towards Devon. Both these manuscript headings convey the scribe's belief that the poem's speaker was traveling a route other than the one modern editors and their readers usually assume was Donne's route in 1613.

Turning to variant readings beyond the headings in the texts of P2 and PT2, Barker listed thirty-five such variants, including the appearance in PT2 of two of the four lines that P2 did not include: "It made his owne Leiutenant Nature shrinke / It made his footestoole crack the Sunn to winke!". Barker was inclined to think that the inclusion of this couplet in PT2 was, like his sense of the PT2 heading, "a progressive improvement" from P2 to PT2; and he pointed to three other PT2 variants (see P2, 11. 5, 13, and 25, tabulated against PT2 and against Gardner's text in Appen-

8. Cf. Thomson and McKitterick 1974, 871, where the P2 heading is described as "a contradiction of what has hitherto been known or assumed about the genesis of the poem".

9. See OED, "west country, n. [. . . ] the district or region towards the west; spec. the south-western counties of England (Somerset, Devon, Cornwall, etc.)", Wales being considered not a part of England. 
dix C, pp. 88-89) tending to confirm this sense through their relative nearness to the text of the 1633 edition. Compared to P2 readings, these PT2 readings do seem closer to 1633. But then Barker noticed that PT2 also reads "board" against "peir'ced" in 1.18 of P2, whereas in 1633 the reading was again "peirc'd". He concluded that "board" in PT2 was a scribal error rather than an "improvement"; moreover, he found the punctuation of PT2 to be "looser and less frequent" than that of P2, again conflicting with his initial perception of "a progressive improvement" from P2 to PT2.

Nevertheless, Barker still accepted the conjecture of Thomson and McKitterick that P2 preserved authorial readings subsequently revised away by Donne. Various unspecified readings of both P2 and PT2 against the text in 1633 he judged to be "clearly errors" tending "away from the original to the conventional". But he judged also that the presence of such trivializations "does not mean that all the variants are scribal errors" and that possibly P2 and PT2 may indeed be "the earliest surviving texts" of Goodf. Like Croft, as well as Thomson and McKitterick, Barker did not offer any bibliographical argument for this conjecture, which, like theirs, seems to have proceeded, at least in part, from the cogency of variant readings in P2 and PT2; but going beyond Croft or Thomson/McKitterick, he attempted to account for the close relationship between P2 and PT2. Discussing the incidence in both manuscripts of words struck through and inserted, Barker further observed about P2 and PT2:

The only reasonable explanation of the two versions by the same hand is that both were copied by a scribe who wrote too quickly. He tried to memorize two lines or more at a 'take', and did not 'hear' the text clearly as he wrote, hence the number of unmetrical lines and the aurally impossible 'thyne mercye' [in 1. 34 of P2, where Barker noticed the scribe's immediate correction of his own error]. He corrected [in PT2] some of the errors, perhaps later and in the absence of the text copied. $(1974,997)$

In other words, Barker thought that the scribe had first copied P2 with haste and carelessness, later correcting some of these errors in PT2, but also committing some new ones. Barker concluded by stipulating that Rich's transcriptions "are not unimportant, even if they are careless". He quoted Croft's catalogue entry for the sale of PT2, which "stated that 'contemporary manuscripts of single Donne poems are decidedly uncommon'. This may well be the form in which his poems were originally circulated; it is possible that [P2 and PT2] are the earliest surviving texts" of Goodf. 
Following Barker's intervention, the TLS exchanges about these manuscripts were concluded when Croft with R. E. Alton identified the scribe of both P2 and PT2 as Nathaniel Rich, a kinsman of Lady Cary (1974, $1042-3) .{ }^{10}$

The next published discussion of P2 and PT2 was in Helen Gardner's 1978 revision of her 1952 edition of Donne's Divine Poems. Gardner devoted a supplementary note to the two newly discovered manuscripts; but she dismissed both as "clumsily corrupt versions [. . . of no value to an editor". She did not refute nor even mention the conjectures of Croft, Thomson/McKitterick, and Barker that what the scribe was copying in P2 and PT2 may have been a version of the poem antecedent to the 42-line version witnessed in the manuscript Groups and early editions. Without acknowledging this possibility, Gardner nevertheless confronted a distinctive profusion of variants in the newly discovered manuscripts. Faced with all these, but assuming for no stated reason that Nathaniel Rich can have read and tried to transcribe only a version of the poem resembling the rest of the manuscript tradition, Gardner offered no analysis nor pointed to any significance of what she termed "errors" and "omissions" of P2 and PT2 but merely declared that Rich had been unable to make less botched copies. On the other hand, citing Alton and Croft, she commented that what is known of Nathaniel Rich "makes it seem highly unlikely that he would copy a document so incompetently". Accordingly, she conjectured instead that both P2 and PT2 represent efforts by Rich to remember a text he had read but had not immediately been able to copy; she thought them both attempts to "write out the poem from memory", PT2 (the second attempt) copied "with "improvements" $(1978,156){ }^{11}$

10. Alton and Croft offer, as well as identification of the handwriting, some important biographical information about Rich and his friendship with Donne; and they add this description of "the box in which lay the manuscripts erroneously attributed" to Donne: "The student will also discover that there is nothing in this clutch of Rich papers which would deny the probability that the copies of 'Good Friday', though inefficient, are none the less early: some of the documents are dated, others equally clearly belong to the period before Rich was knighted [in 1617], and on paleographic grounds there is no reason why the two copies of Donne's poem should not also antedate that event" (1974, 1042-3).

11. In addition to the supplementary note (156-7), Gardner changed some things pertinent to P2 and PT2 in her "Commentary" on Goodf (98-100). She added to the textual headnote manuscripts and miscellanies that had come to light since her previous edition, excluding, however, P2 and PT2 from these lists and referring the reader "for discussion of two copies in the hand of Sir Nathan- 
This notion is related to one that Barker had considered in order to unfold the relationship between P2 and PT2; indeed, Gardner may have been alluding to his article by placing otherwise unexplained quotation marks around a word he used to convey his uncertain impression that transcription of the poem underwent "progressive improvement", in some respects, from P2 to PT2. However, not only did Gardner make no reference to the conjectures of Croft, Thomson/McKittrick, and Barker that P2 and PT2 may stem from an authorial version of Goodf antecedent to a revised version witnessed in the manuscript Groups and early editions; she presented no analysis of $\mathrm{P} 2$ and PT2 variants in relation to what she supposed was their common basis in some version of the 42-line text printed in 1633. In the final sentence of her supplementary note, raising en passant a historical/biographical question and enunciating a standard bibliographical maxim, Gardner alluded to the contention that P2 and PT2 might be early versions of the poem: "Although Sir Nathaniel delivered a letter to Donne in Paris in 1612, this need not mean that they were closely acquainted, and although the copies in his hand may well be early ones, it is a common fallacy in textual criticism that an early date is any guarantee of the value of a text" $(1978,156) .^{12}$ Thus Gardner fenced with the conjectures of Croft, Thomson/McKitterick, and Barker while leaving them unattributed and unexplained.

Instead, Gardner insisted, "Differences from the text of 1633, often damaging to the metre, in most cases substitute more conventional wording. The omission of two couplets (11. 17-20) in [P2] cannot be explained as an eye-slip"; these considerations are what led her to conclude that Rich worked faultily from memory after seeing a copy of the 42-line poem. Interpreting some P2 and PT2 readings (she did not specify which ones) as

iel Rich" to the supplementary note. She also, as noted above, omitted from her commentary on the text the phrase "genuine alternative readings" that Stringer (2002) would quote from her 1952 edition. Essentially following Gardner, the most recent editor of Goodf similarly mentioned Rich's transcriptions but dismissed them as "very defective" (Robisns 2010, 563). See also Todd (2001, 205 and 207), in substantial agreement with Gardner that P2 and PT2 are merely defective memorial reconstructions of the version in the manuscript Groups and early editions.

12. Conceding that P2 and PT2 may well be early copies of the poem but that that circumstance alone does not make them valuable to an editor, Gardner was disputing Barker and Alton and Croft without naming them. Cf. Barker's review (1973) of Gardner's essay accompanying the publication of a facsimile of the holograph of Carey. 
trivializations, "more conventional" than the readings of the manuscript Groups and early editions, she did not make a bibliographical argument. Gardner did, however, ask about Rich's transcriptions, "what was the source of the text, and why did Sir Nathaniel write the poem out twice?". ${ }^{13}$ These questions are much to the point, but Gardner offered no answer to either of them. Instead she repeated her assumption that "errors" in Rich's two transcriptions "seem much more like the results of a faulty memory than of a failure to transcribe accurately from a written text" $(1978,156)$.

Gardner mentioned what she described as P2's and PT2's "omission" of lines only in order to maintain that Rich did not copy from a written text. Her assertion that the absence of lines appears to result from bad memory rather than from faulty copying is an assertion textual editors may make; but in this case its validity depends on accepting Gardner's assumption that what Rich knew was some version of the poem similar to the 42-line version Gardner had used as her copy-text. Neither Gardner nor any other editor has presented bibliographical evidence to support this assumption. Gardner did not dispute nor even mention the contention expressed by Croft, Thomson/ McKitterick, and Barker that these lines might have been added to the poem at some point after Rich copied it.

In fact, a striking characteristic of both P2 and PT2 is that, compared generally to manuscript versions of Donne's poems, the lines that seem to be missing from them are not certainly omissions, an uncertainty that makes it more difficult than Gardner seems to have thought to render secure bibliographical judgment about them. Apparent omissions occur at various places throughout manuscript and print versions of Donne's poetic canon. Rarely is the omission apparent only by comparison of the shorter version of the poem to a longer one; usually the omission creates an obviously faulty reading. There are exceptions to this. A manuscript of the verse letter to Rowland Woodward beginning "Like one who in her third widowhood" (RWThird) has one fewer triplet than other versions of the poem, and the deficiency creates no difficulty in the poem's structure or argument (Donne 1967a, 466). ${ }^{14}$ By far, however, the majority of such incidents yield a demonstrably false reading or are like the one in Sat2, lacking

13. Gardner's use of Rich's title here probably does not register her assumption that he made his transcriptions after being knighted in 1617. Note that in the passage quoted above she writes that "Sir Nathaniel" visited Donne in France in 1612.

14. One editor, John T. Shawcross (Donne 1967a), lists WN1 as omitting lines $16-8$. 
in two manuscripts 1.46 ("Like nets, or lime-twigs, wheresoever he goes"), an instance where the omission does not distort the syntax of the passage but does distort the rhyme scheme (Donne 1967b, 8). ${ }^{15}$

Of twenty-four extant manuscript versions of Goodf, several have fewer than the forty-two lines most common among the manuscript versions and found in early editions. One version (C1) is a witness of only two lines. Five others might well be characterized as missing or omitting lines: 11. 24-5 are omitted in four out of five Group I manuscripts (C2, C8, O20, and SP1), and two of these (C2 and $\mathrm{C} 8)$ also lack 11. 22-3.16 All of these omissions clearly are omissions, interrupting one or more couplets and compromising the logic of the poem's syntax. The circumstance that 11.23 and 25 both end with a rhyme on is makes it likely that a common error of transcribers, an eyeskip from 1.24 to 1.25 , is responsible for these omissions. One other omission, of 11. 36-8 in another manuscript (B13), is less obviously mistaken. Without these lines, the argument and syntax of the poem remain intact; but the omission produces a triplet, the first two lines of which rhyme on me. In contrast, what, in comparison to the 42-line poem, seem to be the omissions of P2 and PT2 are not at all evidently omissions; they interrupt neither the rhyme pattern nor the logical flow of the poem. In the cases of P2 and PT2, a reader with no prior sense of the poem in its 42-line form would not notice anything amiss. The circumstance might well invite the question broached by Croft, Thomson/McKitterick, and Barker: are P2 and PT2 corruptions of a fully realized poem, or do they in some ways reflect the poem in earlier stages of its composition before Donne gave it the form later embodied in the manuscripts of the Groups?

Such authorial revision was at one point specifically hypothesized by Barker to explain what seemed to him an "improvement" of P2 in PT2. Directing attention to the two lines in PT2 that do not appear in P2 - "It made the earth to $\wedge$ his footestoole $\wedge$ crack and the Sunn to winke!" - he commented, "Did the scribe forget that vivid metaphor — an abrupt recollection of Isaiah 66 - and substitute his prosaic paraphrase of the Gospels, correcting it from his exemplar? Or did he have access to an autograph that originally lacked this passage, which Donne added in some part and

15. The apparatus of Wesley Milgate's Oxford edition of Donne's satires, epigrams, and verse letters (Donne 1967b) lists B32 and NY3 as omitting the line; his stemma (lxi) adds O20 and SP1.

16. One Group I manuscript, B32, records lines 24-5, thus demonstrating conclusively that the Group I exemplar had all these lines and thus pointing to a single scribe as the source of the omission. 
form, perhaps even making the amendment his footestoole after the scribe had copied Hofmann [i.e., PT2]? As things stand, these questions cannot be answered". Barker's TLS piece did not, however, end with this skeptical sentence: "There is more", he continued, "to be made of this"; and he foresaw that identification of the scribe (soon subsequently made by Alton and Croft) could be a crucial element in a more complete understanding of the significance of these manuscripts.

No bibliographical evidence can at this point decide the question of whether P2 and PT2 are corrupted or prior versions of the 42-line poem. This question cannot be addressed at all effectively, however, without acknowledging another contention by Barker that Gardner did not mention but apparently disagreed with: that P2 and PT2 were each written by a scribe working from a written text. That Rich in P2 was working from a written text is rendered very likely by the relatively clean condition of most of its lines and by the nature of some of its corrections. ${ }^{17} \mathrm{~A}$ case in point is line 29- "Theise things are as thus I ryde, are from myne Eye" - where the correction of are to as seems a good illustration of the phenomenon Barker characterized as a scribe working quickly, anticipating are from the second part of the line he has looked at, and beginning to introduce it prematurely as he turns away from his text to write it down. Another, as Barker suggested, seems to have occurred in line 34, when Rich mistook thyne for thy and then deleted ne when he realized thyne was incompatible with the rest of the line. At the same time, however, the appearance of 11. 9-10 in this manuscript suggests something more complex going on than scribal anticipation:

Hence is it that his day I goe vnto $\wedge$ trauayle vnto^ the West $\wedge$ This day, $\wedge$ when my Soules forme tends vnto the East.

Rich may well have been working quickly and anticipated this day from line 10 in line 9, putting down both lines with this day in the wrong place and then correcting it when he looked back at his text. But when he went back

17. TLS for August 16, 1974, cover, and 20 September 1974, 996, reproduce images of, respectively, P2 and PT2. An image of P2, taken from a photocopy of the manuscript made by the Huntingdonshire Archives when it was in their possession and used here with their permission, is linked to Appendix A, p. 85, transcribed on p. 84; and an image of PT2, now in the Robert H. Taylor Collection of the Department of Rare Books and Special Collections, Manuscripts Division, of Princeton University and used with their permission, is linked to Appendix B, p. 87, transcribed on p. 86. 
to repair line nine, he changed goe unto to trauayle vnto, a change that suggests a mind at work underscoring with trauayle the exertions of pleasure and business that are drawing the speaker westward. Thus Barker agreed with Thomson and McKitterick that, while these revisions in P2 could conceivably represent scribal corruption, it cannot be demonstrated that they are not authorial. ${ }^{18}$

PT2 has even more the look of a manuscript copied by someone occasionally anticipating himself and so, perhaps in view of his copy-text, needing to make corrections but also introducing revisions as he does so. The correction of sitt to sett in its line 11 is what is likely to occur when a scribe looks back over the line he has copied and sees the need to distinguish decisively the two words. Likewise, the insertion of lines 5 and 6 seems to indicate a scribe reading what he has written against his copy and repairing an omission. But, as Barker asked, what can explain Rich's writing in PT2, 1. 20, "board through $w^{\text {th }}$ Holes" when he had in P2, 1. 18, written "peir'ced through $\mathrm{w}^{\text {th }}$ holes"? Barker thought this a scribal error, but it may have stemmed from authorial revision: "board" is neither "conventional" nor a "trivialization" compared to "peir'ced". Nor do P2's and PT2's "Scoure" (11. 36 and 38 respectively) conventionally trivialize "Burne" (1. 40 in the Groups and editions). There is, moreover, a striking adjustment, most especially of the modal verbs, in the first line of the couplet describing the mother of Jesus, from "Or if on these things I could looke, durst I" to "And if on these I durst not looke, dare I" (1. 25 in P2, 1. 27 in PT2). Barker was right to call attention to the unusual fussiness in PT2's presentation of the lines (19-20) that do not appear in P2. It is also interesting that Rich seems to have stumbled again over 11. 9-10, the lines that he reworked in P2. The that he inserted into line 9 may have been at first the result of his recalling

18. According to Stringer 2011, scribal corruption is an inevitable and confusing characteristic found throughout the manuscript transmission of Donne's writings: "As these works passed along the channels of manuscript circulation, copyists inevitably misread their predecessor's handwriting, made slips of the pen, lost track of their place in the copy-text, decided to 'improve' the poem as they transcribed it, or found themselves baffled by the sheer difficulty that Donne's poetry sometimes presents, and the cumulative result of these actions [. . .] can be a welter of confusion". At the same time, it is also true that Donne himself introduced authorial revisions into the same process: "An additional factor complicating the interpretation of the manuscript evidence is that Donne revised many of his poems over the course of time, some of them more than once, and sent these revised versions into circulation alongside the originals, begetting strains of authentic variation within the surrounding sea of error" $(18,21)$. 
what he had written in P2 before he realized that the change of is'it to it is altered the meter of the line so that that would distort the pronunciation of trauayle. If that change, from is'it to it is, is a scribe's mistake, Rich adjusted the line to accommodate it rather than correcting the error. If it is a change made to the poem from the version Rich copied in P2, it registers a revising mind at work, Rich's perhaps, but (Barker is right to introduce the possibility) maybe the mind of Donne himself. Barker's thinking in these matters is, in one respect, similar to Gardner's theory of Rich's writing the poem from memory. Both posit a mind at work recalling a version of the poem and, for better or worse, adjusting it. Barker's sense of the intelligence at work, in contrast to Gardner's, however, is that it is a deliberate one and sometimes impressive in its deliberation.

Such deliberation gives point to a striking quality of both P2 and PT2: that, compared to manuscripts acknowledged as scribal trivializations and other corruptions, they are coherent poems with a distinctive cast, crucially different from that of the 42-line version of the poem. Like the 42-line version, the P2/PT2 versions represent a speaker in the process of coming to understand how his westward journey can be a devotional act. The argument of both P2 and PT2, however, depends on the speaker's justifying the direction of his journey in the present by connecting it to his distance in time from the first Good Friday. That is, in both of these versions of the poem, the speaker's journey in a direction away from the sight of the crucifixion is an occasion for him to reflect that he is almost glad he "did not see" it (1. 15 in P2/PT2) at the historical moment when it occurred. This differs from the argument of the 42-line poem, in which the speaker, consistent with the orthodox understanding of the sacrifice of Calvary as an ongoing event that a devout penitent can always witness, is almost glad he "do[es] not see" it (1. 15) because of the direction of his journey..$^{19}$ As in the 42-line poem, the condition of the speaker in P2/PT2 is resolved by his realization that memory is the capacity to look back; but in P2/PT2, "back" is temporal before it is spatial. The speaker of P2/PT2 begins to contemplate the spectacle of the crucifixion as he recalls details of the scriptural record of the event, a circumstance made more explicit in PT2, compared to $\mathrm{P} 2$, by the addition of 1.18 , "It made the ${ }^{\wedge}$ his footestoole ${ }^{\wedge}$ crack and the Sunn to winke!". The poem recorded in P2 and PT2, notwith-

19. Chambers (1987, 6: 185) comments on the speaker's unusual acknowledgment, in 1.15 of the 42-line poem, of "what might be observed if one took the trouble to look". The speaker of P2 and PT2 at first does not understand that looking back, through the faculty of memory, is a possibility. 
standing differences in wording that may be more or less admirable, is the record of a different psychological trajectory for its speaker. This might be because the refracting intelligence of Rich consciously or unconsciously moved what he absorbed of the 42-line poem in that direction. Or it might be because the P2/PT2 versions record Donne's first conception of a poem he later revised.

If either P2 or PT2 were its only witness, Goodf would still be valued as a remarkable poem with some particularly noteworthy words and phrases. A distinctive feature of $\mathrm{P} 2$, in particular, is its repetition of the phrase "this day" in 1.13 , which has already occurred in 1.10 (apparently inserted after being canceled in 1.9), another of the places where PT2 differs from P2 in a way that moves it in the direction of the manuscript Groups: "this day" in P2 becomes "the Cross" in PT2 and is "this Crosse" in 1633 Poems or "thys Crosse" or "his Cross" in the Groups. The repetition of "this day" in P2 could be put down to a memorial anticipation; but it is equally likely to be an emphasis on the immediacy of the mental experience P2 records. In 1. 9 of both P2 and PT2, the word "trauayle" (inserted above the line in P2 to replace a canceled "goe") emphasizes not only the agency of the speaker in pursuing "Pleasure, and Business" (line 7 in P2 and PT2) but also some sense of oppressive exertion in doing so; and it contrasts pointedly with the verb in 1.10 describing how his "Soules forme tends vnto the East". This perhaps hypermetric line, accommodating unto instead of a monosyllable like to or an elided toward, underscores the contrast between what the speaker is actively doing ("trauayle"-ing) and what his soul less concertedly "tends" to do. ${ }^{20}$ Also notable are the different degrees of the speaker's capability to endure the spectacle of the Virgin Mary's grief faced with the mangled body of her son: in P2, 1. 25, he asks, "Or if on these things I could looke, durst I [. . . ? "; in PT2, 1. 27, he asks, "And if on these I durst not looke, dare I [ . . ]?". The hands of Jesus are "board through $w^{\text {th }}$ Holes" in PT2, 1. 20, a reading Barker thought inferior to "peir'ced" in P2, but that in its vividness seems to be moving in the direction of "Scoure" (1. 36 in P2, 1. 38 in PT2) as opposed to "Burne" in the 42-line poem and "rent" (P2, 1. 24, and PT2, 1. 26), compared to "rag'd" in the 42-line poem (1. 28). "Correction" (1. 34 in P2, 1. 36 in PT2), like "trauayle", admits a quibble that the 42-line poem avoids but like P2's emphasis on "day" is noticeably involved with the situation of the poem's pretext. As chastisement or punishment it will scour

20. Cf. OED, "tend, v.2 [. . . 2. fig. a. intr. To have a disposition to advance, go on, come finally, or attain to (unto, towards) some point in time, degree, quality, state, or other non-material category; to be drawn to or towards in affection". 
away the rust and ugliness of the speaker's sinful condition; but etymologically, a possibility that is obscured in the plural form it has in the 42-line poem, it suggests a reorientation, a return to going right, east on a map.

None of these variant but quite coherent readings has been shown a scribal error rather than a tentative authorial trial. They could conceivably have resulted from Rich's mistranscription or mistaken recollection of an earlier poem perhaps already flawed by mistranscription; but if this is the case, their accidental coherence seems unusual, if not unlikely. If they are to be attributed to Rich, he imposed on his work a coherence that renders each of the two versions of the poem he transcribed interesting in its own right, giving him a claim to poetical abilities worth comparison to Donne's own. But the comparison is even more warranted if we entertain the conjectures of Croft, Thomson/McKitterick, and Barker that P2 and PT2 may in some way reflect Donne's earlier articulations of his poem's argument, later revised to the version of the poem recorded by the manuscript Groups.

\section{Donne's Journey into Wales in April 1613}

Full discussion of P2 and PT2 must dwell further on the remarkable headings given the poem by Nathaniel Rich. In the absence of bibliographical evidence to determine whether P2 and PT2 stem from the same holograph as the 42-line version of the manuscript Groups and early editions or whether they stem instead from an earlier, authorial version, Rich's headings, strikingly detailed and particular, provide occasion to develop other kinds of evidence that, brought to bear on the poem, may illuminate some of the problems so far addressed in this essay.

Neither of Rich's headings, "meditation vpon a Good friday, ryding from London towards Exceter, westward" (P2) and "Meditation on a good friday ridinge from London into y $y^{\mathrm{e}}$ West Countrey" (PT2) - which Gardner and others have found merely inaccurate - seems likely to have been transcribed carelessly and erroneously from any of several very different headings that appear in various manuscripts of Groups I, II, and III. Nor can these two headings plausibly be regarded as errors of memory. Working from memory to make a copy of a poem, one may forget and mistake words or even entire lines that one once heard read aloud; one may as well forget and mistake words and lines once read. But in supplying for this poem the only two extant headings that specify not only when but where the poem was written, Rich (who was to distinguish himself, as will be discussed below, as a careful and focused parliamentary note-taker) would seem unlikely to have misremembered. 
In both P2 and PT2, as Barker observed, the headings seem to have been added after the text was inscribed. In P2, the letters of the heading are smaller than those of the text, suggesting that Rich originally wrote out the poem with no heading and then squeezed one in after transcribing the text; he then underscored the heading to separate it from the poem itself. In the case of PT2, Rich again evidently wrote out the text of the poem and then squeezed in the heading in smaller script at the top margin, this time depending on spacing to create some separation from the text of the poem. This similar treatment of the headings in each of these two manuscripts is evidence that Rich was not in either case copying the headings from an earlier copy of the poem. Were he to have had someone else's copy of Goodf in front of him, with so emphatically specific a heading as each of these, he would likely have written it first, as part of the copy he was making, in usual scribal fashion - engrossed and/or spaced generously at the head of the sheet.

Rich's headings denote that the speaker of Goodf is to be imagined traveling in a southwesterly direction from London (both P2 and PT2, and only these manuscripts, specify the speaker's point of departure) towards Exeter in Devon, in the "West Countrey". On the other hand, Donne's editors and biographers have all connected Goodf with an assumption supported by no extant heading that in April 1613, on his way to Wales, Donne's itinerary was northwest from London, pausing north of Coventry at Polesworth, the estate of his friend Sir Henry Goodere, on the way to Montgomery. This usual way of thinking was probably Gardner's thought when she claimed that other, unspecified manuscript evidence contradicts the heading of $\mathrm{P} 2$; in fact there is no such contradictory evidence in any manuscript. In another mistaken argument of the usual way of thinking, R. C. Bald quoted the heading of the Group III-associated manuscript B13, " $\mathrm{M}^{\mathrm{r}}$. I: Dun goeinge from $\mathrm{S}$ r H: G: on good friday sent him back this Meditacon, on the Waye", as if this heading could show that Donne visited Goodere at Polesworth on the outward leg of his journey. In fact, there is no evidence that this was the case. Gardner, Bald, and others have simply assumed that Donne wrote his meditation on the road from Polesworth to Montgomery. ${ }^{21}$ Although the B13 heading states that Donne, "goeinge

21. Bald 1970, 270. See also CArey 1981, 119-20, and Kay 1986, 37: 209. B13, like P2 and PT2, is remarkably explicit about details of the journey that inspired the poem; the prevailing response has been to privilege B13's over P2's and PT2's headings because the text of B13 is closer to editors' chosen copy-texts. In fact, B13 may well be considered at least as defective as P2 or PT2. It actually has fewer lines than PT2, and one of its variants ("God fall" for "God's face" in line 
from" Goodere, "sent him back" Goodf "on the Waye", and although the poem itself states that the poet was riding westward as he wrote/composed, the phrases "sent him back" and "on the Waye" may not refer to the road from Polesworth to Montgomery. It is not even certain that Goodere was at Polesworth when Donne "sent him back" a copy of the poem; he may have been at London. And even if Goodere did receive the poem at Polesworth, it does not follow that Donne sent it on the road from Polesworth to Montgomery. Donne may have sent it by way of London to Polesworth from some point on the road to the west country, at least as likely a road on which to have procured a carrier as the road from Polesworth to Montgomery.

Figure 1 shows Donald Hodson's representation of the routes most frequently traveled by post-stage in Jacobean England. Each small dot along these roads represents a post-stage, where horses were available for hire and exchange. A direct route for travelers between London and Montgomery would have been the main route from London via Coventry to Shrewsbury (indicated by a double-headed arrow), and thence on local roads southwest into Wales. If (as Gardner, Bald, and others have thought) Donne used this route both ways, visiting Goodere at his Polesworth, Warwickshire, home on the way to Wales, he would have taken local roads north of Coventry, a diversion off his main route. After his stay with Goodere, in this surmise, he would have returned to and continued on the main road connecting London and Shrewsbury.

On the other hand, Figure 2 is a detail of Hodson's map, with arrows indicating an alternative itinerary Donne could have used on his outward journey to Montgomery, an itinerary other than the usually supposed, northern route. While the hitherto accepted route would have been more direct, Donne could have used this alternative route from London towards Bristol and then north into Wales towards Montgomery. He could later depart Montgomery by the most direct route back to London, briefly northeast to Shrewsbury but then southeast, making a visit to Polesworth north of Coventry, not on the way to Montgomery but on the way back to London. This itinerary suits with the two all-but-ignored headings of the generally dismissed P2 and PT2.

17) eliminates the reference to Ex. 33.20 that leads into line 18. Like several other witnesses, it also appears to distort the rhyme of 11. 23-4 by adding "to" before "our Antipodes" and not indicating an elision with "our" as three other 42-line manuscripts do. See the discussion of the relationship between B11 and B13 in Sмiтн 2014, 248, n. 16. 


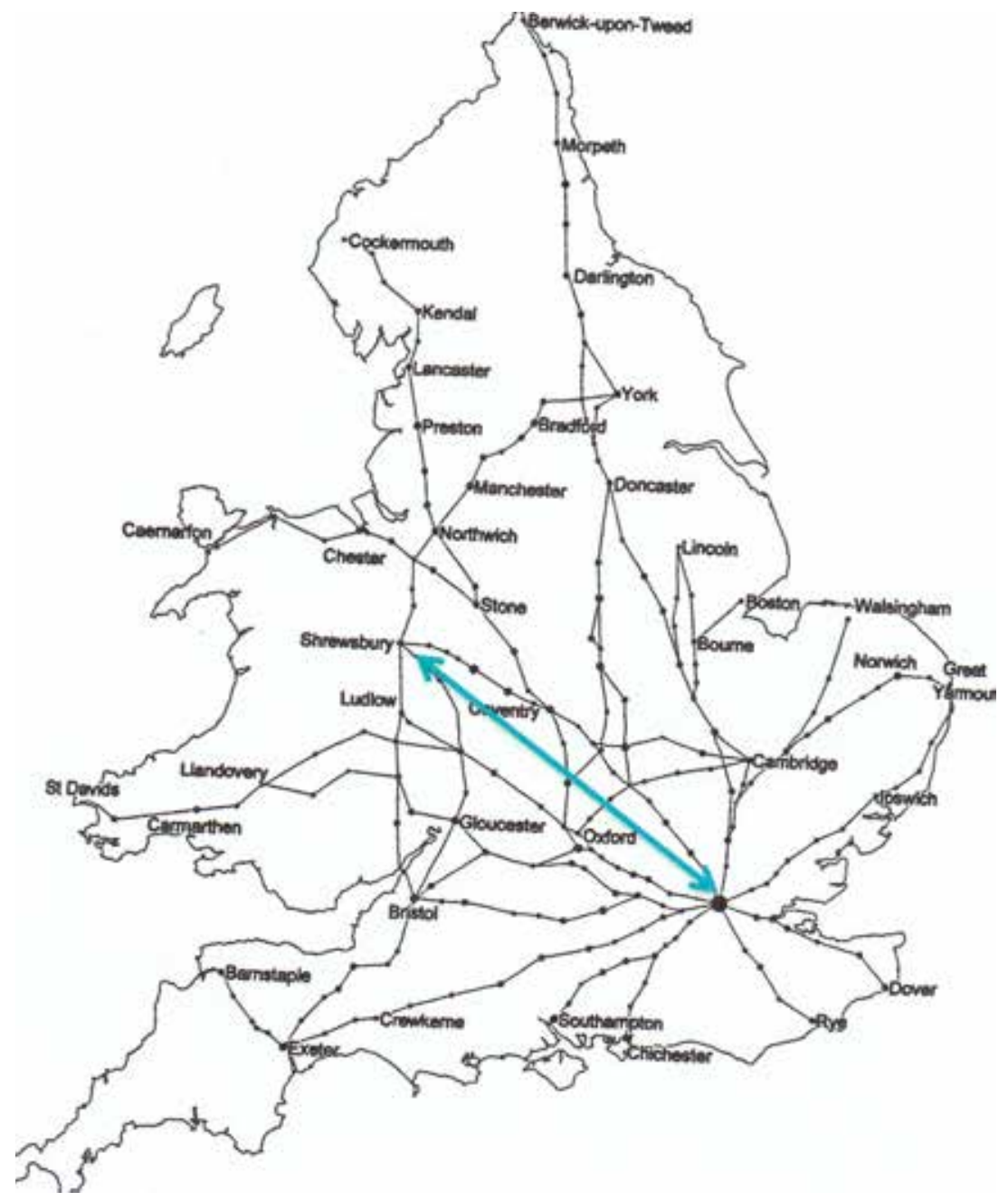

Figure 1. Thirty-seven most frequent routes traveled by post stage in Jacobean England; Donald Hodson, "The early printed road-books and itineraries of England and Wales" (University of Exeter, unpublished thesis, 2000), 201.

In considering these alternatives it is useful to review all the extant manuscript headings of the poem (see Appendix D) with their various information about where and when Donne wrote Goodf. Many of these headings are tantalizing in the details they provide. In some ways the most interesting is the authorially flavored heading of the Group II manuscripts, "Good friday Made as I was Rideing westward, that daye". This 


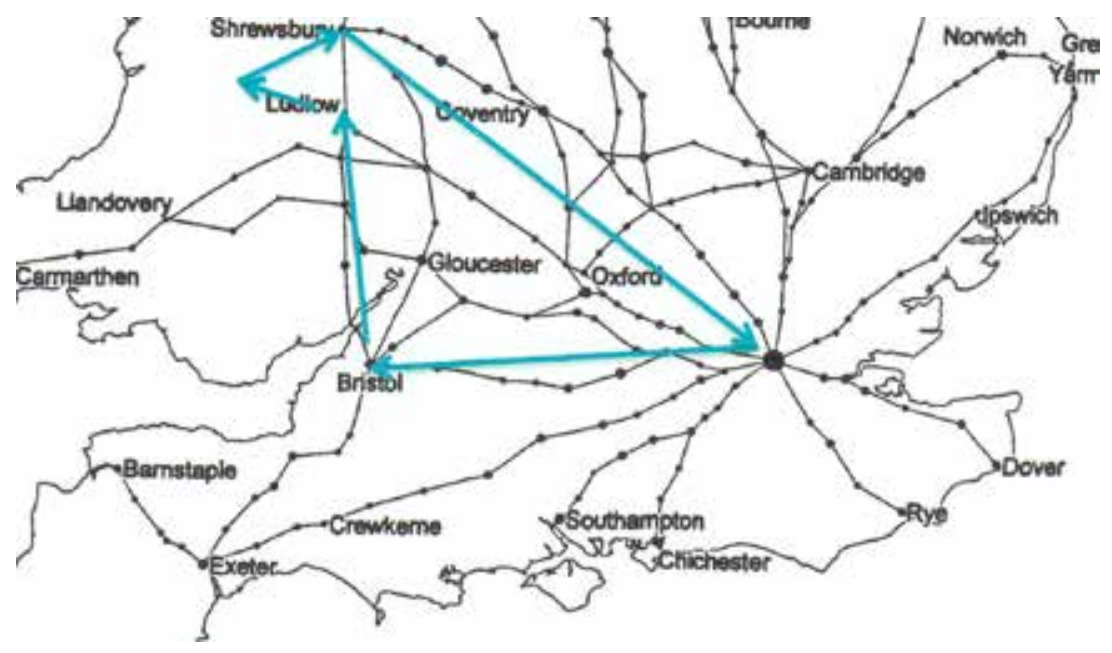

Figure 2. London-Bristol-Montgomery-Shrewsbury-Polesworth-London.

heading is compatible with the usual thinking about Donne's itinerary, since if Donne left Polesworth in a northwesterly direction on Good Friday he would indeed have been riding westward towards Montgomery. Similarly compatible with the usual thinking are most of the other manuscript headings: "Goodfryday. 1613. Ridinge towards Wales" (the heading in the Group I and Group III manuscripts) and all the headings in Group IIIassociated manuscripts (including B13's "Mr. I: Dun goeinge from Sr H: G: on good friday sent him back this Meditacon, on the Waye").

Gardner offered two dismissive assertions about the heading of P2: (1) that its information about Donne's itinerary "contradicts information given in other manuscripts"; and (2) that this heading is "inconsistent with what we know of Donne's movements in the spring of 1613". Both these assertions are mistaken. The headings of P2 and PT2 do contradict the usual thinking about Donne's itinerary. But careful comparison will show that they do not contradict information in any of the other ten extant headings nor are they inconsistent with anything we know of Donne's movements. Unless the unsupported assumption that Donne visited Goodere at Polesworth on the way to Montgomery is credited, all the various headings may be correct. Nothing in these headings or elsewhere on record can contradict the headings in P2 and PT2. In other words, if the Figure 2 itinerary was Donne's itinerary, and if Donne began to compose the poem riding towards Exeter or into the west country, he was or may also have been (1) "Rideing westward", (2) "Ridinge towards Wales", (3) "Riding to 
$S^{r}$ Edward Harber in wales", (4) absorbed in "A Meditation Vpon Good ffriday", and even (5) "goeinge from $\mathrm{S}^{\mathrm{r}} \mathrm{H}$ : G: on good friday", when he "sent him back this Meditacon, on the Waye". This last, the heading of the poem in B13, implies simply that a copy of the poem was sent "back" to Goodere on Good Friday, when Donne was traveling away from Goodere's location. This place, some have assumed, was Polesworth, whence Donne had departed on the outward portion of his journey; however, no extant heading of the poem states or even implies that Donne was at Polesworth before he departed for Wales, nor for that matter does the poem itself.

The possibility that Donne's itinerary was the one described in Figure 2 prompts further consideration of Nathaniel Rich's two headings, stating that Donne traveled on Good Friday from London towards Exeter or the west country. More fundamentally, it also prompts further consideration of Gardner's two hitherto unanswered questions about the source and occasions of Rich's texts: "what was the source of the text, and why did Sir Nathaniel write the poem out twice?". These are queries that address the issue of where Rich got his distinctive ideas about Donne's itinerary; and the material sense they make, in the absence of any evidence to the contrary, is that Rich had knowledge, if not experience, of Donne's journey. Though both headings are followed by texts of the poem that have been thought inaccurate, P2 and PT2 are among a very small number of Donne manuscripts whose scribe can be identified as a friend of Donne's; the argument that Donne's acquaintance with a scribe translates into some kind of presumption of textual authority has to be handled with a great deal of caution. But manuscripts in the handwriting of Donne's friends are certainly entitled to a measure of regard not routinely extended - e.g., NY3, the Westmoreland manuscript, in the hand of Rowland Woodward (Stringer 2002, 134).

What is known about Nathaniel Rich is therefore germane to a consideration of P2 and PT2. According to George Yerby and Rosemary Sgroi (2010, 6: 32-3), like all his cousins Nathaniel Rich had been "brought up with a strongly puritan outlook". He had been educated at Cambridge and Gray's Inn "for a career as man of business to his cousin the third Lord Rich (Robert Rich) and to the latter's son Sir Robert Rich".22 Nathaniel

22. Worth noting here is the fact that Rich's father was the illegitimate son of Sir Richard Rich, solicitor-general under Henry VIII, whose uncorroborated testimony about his interview with Sir Thomas More in the Tower of London on 12 June 1535 was the sole evidence to convict More of treason at his trial on 1 July 1535 for denying the royal supremacy (CARTER 2004). 
Rich had delivered a packet of letters to Donne, probably at Amiens, where his cousin Sir Robert also joined Donne early in $1612 . .^{23}$ It was probably while the three men were at Amiens (with Sir Robert and Anne [Bacon] Drury) that Donne wrote Carey, perhaps at the request of Nathaniel and/ or Sir Robert Rich, perhaps also arranging for one of the men to deliver or forward a copy or copies of the verse letter to the two sisters in England.

Though Gardner simply dismissed the thought that any authority might attach to Rich's transcriptions, noting that his delivery of a letter to Donne in France in 1612 "need not mean that they were closely acquainted", the poem Carey is evidence that Donne's acquaintance with the Rich family in 1613, however intimate it may or may not have been, was fresh and active. Moreover, Nathaniel Rich's repeated travel at this time into the English west country is on record. In 1608 one of the sisters referred to in Donne's verse letter from Amiens, Lettice Rich, had married in her twenties the sixty-seven-year-old Sir George Cary of Cockington, Devon,

23. That Rich's delivery of mail for Donne took place at Paris was an assumption of Alton and Croft (1042), followed by Gardner (1978, 156), citing evidence in a letter by Donne that certainly was written from Paris in April 1612: “ [. . . I received (as I told you) a Letter by M. Nat. Rich [. . .]" (Donne 1651, 74). However, as the context of this passage makes clear, Donne was not referring to this delivery as a current event but was reviewing a series of incidents involving his correspondence on the continent during the previous three months, during most of which Donne had stayed at Amiens before moving on to Paris.

Work on the dating of this and other letters Donne wrote has suggested the likelihood that both Nathaniel and Sir Robert Rich were with Donne at Amiens before Donne went to Paris towards the end of February or beginning of March 1612. Along with these occurrences, other occasional Rich associations are mentioned in the 1651 Letters (see Donne 1651,75, 92, 133, and 246). See also Carey, addressed from Amiens and implying (in 11. 10-5 and 52-4) that Donne had first been told there about the virtues of Lettice (Rich) Cary and her sister Essex Rich.

Another poetically associated connection between Donne and the Rich family may be AltVic, a verse letter entitled A Letter Written by Sir H. G. and J. D. Alternis Vicibus, that is, a poem written in alternating stanzas by Sir Henry Goodere and Donne. Donne's younger contemporary Thomas Pestell wrote an epigram (1940, 28), On the Interlinearie poëm begott twixt Sr H. Goo: $\mathcal{E}$ Dr Donne, suggesting, by describing the two authors as "rich rauisht spirits" $(1940,28)$, that the ladies celebrated in the poem were Lettice and Essex Riche.

Nathaniel Rich's aunt Audrey Rich, who was the great-aunt of Sir Robert Rich, had married an earlier Sir Robert Drury, grandfather of Sir Robert Drury, Donne's friend and fellow traveler on his trip to the continent in 1611-1612. 
where his ancestral house stood a few miles south of Exeter. ${ }^{24}$ (As Robbins pointed out [2010, 712], Cary had served in Ireland under the Earl of Essex and subsequently under Lettice Rich's stepfather, Charles Blount, Baron Mountjoy.) During the intervening years, from 1608 to 1613, as is attested by Cary papers in the Devon Record Office at Exeter, both Nathaniel and Sir Robert Rich had been on several occasions parties to continuing negotiation about the Cary estate, traveling from London to Exeter several times during these years to sign documents witnessing the protection of their sister's interests, given the concerns of Cary heirs about this April/ December marriage. ${ }^{25}$

Nathaniel Rich later became a Member of Parliaments from 1614 to 1629, serving with Donne in the first of these. He was knighted in 1617. Yerby and Sgroi observe that as a leading parliamentarian Rich was intellectually involved with key and underlying issues and that he took careful notes during debate in order to "ensure legislative continuity". ${ }^{26}$ Extant examples of Nathaniel Rich's transcriptions of parliamentary debates may be relevant to evaluation of P2 and PT2. Yerby and Sgroi specify that "On either single sheets of paper, or in small paper books, he made his notes in ink, almost certainly during debates, in a style that is characteristically his, using a mixture of longhand and shorthand" $(2010,6: 33)$. Thus by the time he took these notes Rich had become accustomed to copying oral discourse, using shorthand in some instances, notes that could later be

24. Ute Lotz-Heumann's ODNB entry for Sir George Carey (rather than Cary, as Sir George consistently signed his name) says that the marriage occurred "at an unknown date"; but DRO, Cary 4088/1/25 dated 16 March 1609 establishes that the marriage took place in 1608 .

25. Mentioning and bearing signatures of Nathaniel and Sir Robert Rich are, besides DRO, Cary 4088/1/25 (a conveyance of property to Lettice [Rich] Cary), Cary 4088/1/34A (a revocation of the earlier conveyance, dated 14 September 1612), and Cary 4088/1/24 (a new conveyance, dated 15 September 1612). Cf. also TNA, PROB 11/129/581, the will of Sir George Cary, dated 7 August 1614. According to Yerby and Sgroi, Nathaniel Rich was elected MP for Totnes, Devon, in 1614, on the recommendation of the town's recorder Sir George Cary, "who had married one of Lord Rich's daughters" (2010, 6:33).

26. "He was among the first to adopt an elevated notion of the role and powers of the Commons, for instance in questions of judicature; in doing so he demonstrated an extensive knowledge of history and precedent, occasionally challenging the leading legal experts in the House. He was also anxious to ensure legislative continuity between sessions, and perhaps partly for this reason kept notes in every Parliament he attended" (Yerby and SGroi 2010, 6:33). 
used to fill out the substance of what had also been said between points of high interest. According to Conrad Russell, evaluating the note-taking of MPs for his history of parliamentary politics from 1621 to 1629, "it appears unlikely that, even on the best-reported days, more than about a quarter of the words spoken in the Commons are preserved". Different members, however, were concerned to report different things: for example, John "Pym tried to record the balance of arguments on each side of a question, and Rich tried to record the balance of men". Rich's notes were among those of which "the handwriting and the spacing provide evidence of the mood of the House which cannot be reproduced even in the most perfect of editions". He was "an intermittent diarist", selective and rational, not mindlessly transcribing everything said but concentrating with "a peculiarly sharp eye for an approaching crisis", on matters of particular importance to him (1979, xviii and xx). ${ }^{27}$ These more recent accounts of Rich's parliamentary transcriptions cast into an interesting light the characterization of him by Alton and Croft as someone who seems to have "positively enjoyed the act of writing things down" $(1974,1042)$. Even en route as a traveler, Rich may have "enjoyed" noting the main points of something he read or heard.

When Nathaniel Rich stated that Donne had written Goodf while riding towards Exeter or the "West Countrey", he evidently for some time had known Donne, known the road to Exeter, known that Donne had written the verse letter Carey for his cousins Lettice and Essex, and known that a trip by Donne towards Exeter might have been of interest to his cousin residing there with her husband, Sir George Cary. In early 1609, Donne had stipulated in a letter that his library and "the high way, where I am contracted, and inverted into my self", were his "two ordinary forges" for writing letters $(1651,137)$; and the heading of B13 suggests that Donne sent a draft of Goodf, like a verse letter, "back" to Goodere "on the Waye". Rich may even have been recalling such a trip in Donne's company or may have known someone else who would have done so. As its appearance particularly suggests, P2 is a copy of a poem that underwent revision by its copyist. To be sure, what Rich was copying may have been his own earlier attempt to recall the poem from his memory of having read it. But if Rich and Donne traveled together, it is also possible that Rich first set down what he recalled having heard of Donne's process of composing the poem aloud, or

27. Russell cites Rich's manuscript parliamentary diaries in BL, Add. MS 46191; in the House of Lords Record Office; and in Huntingdonshire Archives, Manchester Mss. 58/5. Russell is cited and partly quoted in Yerby and SGROI (2010, $6: 33)$. 
even, when the travelers stopped, may have recorded Donne's recitation of what he had composed so far.

Mark Brayshay has shown that, as one of several royal post-stage routes, by the end of the sixteenth century the road from London to Bristol was in frequent use by travelers (1991, 378-9). Accommodating commercial travel headed to Bristol or passing into Devon and Cornwall, this road was also chosen by numerous gentry interested in holidays at the city spa of Bath, a few miles southeast of Bristol. ${ }^{28}$ The route between London and Bristol was likely used also by gentry bound for Exeter on horseback. Then as now, the Bristol road was used for travel to Exeter despite its being somewhat lengthier than more southerly roads via Winchester and Salisbury. The latter were more common routes for local travel and for pack horses and freight-bearing carts carrying, delivering, and picking up parcels and other mail along the way at various smaller towns between London and Exeter. The Bristol road, offering Bath as an attraction, was a common route for London travelers like Rich and Donne, to Exeter and to Wales.

Leaving London on or about 1 April 1613, Donne would have to travel approximately 220 miles within six days in order to send from Montgomery the letter he addressed to Sir Robert Harley, at his estate in Wigmore, Herefordshire, on 7 April. ${ }^{29}$ For the first leg of this trip, from London to Bristol, endorsements inscribed on letters by Tudor and Stuart postal officers at each of several intervening post-stages show that the distance could be traveled in from 28.5 to as little as 18 hours, an average duration of 22.3 hours for about 120 miles (Brayshay et al. 1998, 276). ${ }^{30}$ If Donne left London (riding in Rich's phrase, "towards Exceter") early on 1 April, he could fairly easily by late on Good Friday, 2 April, have been in the vicinity of Bristol; if he traveled with someone going to Exeter, they would stop at Bristol and then on the morning of Easter Saturday would part company, his companion traveling south towards Devon, Donne north towards Wales.

Donne's trip from Bristol to Montgomery (about 100 miles) would involve a mile-long ferry crossing, "the Old Passage", over the Severn, of less than an hour's duration (PAGE 1972, 54). In addition, post-stage horses

28. Donne mentions Bath as a holiday destination of Goodere's in two letters, on 16 [26] July 1612, from Spa (Donne 1651, 89) and on 22 December 1617 (1651, 208-9); he tells George Garrard that he himself intends a journey to Bath in a letter of 15 August 1609 (1651, 39).

29. This is a holograph letter, BL, Add. ms. 70001/124r-v.

30. Brayshay et al. calculate the journey's length by averaging a total of six sets of endorsements between 1570 and 1620 . 
could be used as far as Ludlow (about 73 miles); comparable to the Bristol road trip, these 100 miles may be estimated to have taken something like 20 hours or the better part of two days. At Ludlow Donne's route would diverge off the main road to Shrewsbury towards Montgomery (about 26 miles); here no post stages were likely in place (to judge from Hodson's map, Figure 1). But even if these final miles took twice as long as post-horse miles, Donne's total would probably amount to little more than five days of travel all told, reaching Montgomery with time to spare before Donne wrote his letter to Harley on 7 April.

If Figure 2 does represent Donne's actual itinerary, we may better explain the opening passage of the letter to Harley that Donne wrote from Montgomery, five days after Good Friday:

I could almost be content to be desperate of seeinge yow, while I ame in thys Cuntry, if I might hope well of $\mathrm{yo}^{\mathrm{r}}$ health. The Conversation of thys Noble gentleman, who refuses mee not in hys house, recompences the want of any company [...].

Here Donne mentions his disappointment at evidently not having been able to visit with Harley because of illness at Harley's estate, Wigmore (in Herefordshire not twenty miles southeast of Montgomery). Had Donne arrived at Montgomery from London and Polesworth via Shrewsbury, he would not have known that he could not visit Harley at Wigmore, unless Harley had written ahead to Montgomery, warning him not to come. But Donne does not mention that he is answering any such warning letter; his phrase "refuses mee not" seems to imply that Donne has been refused admission at Wigmore, having been to Harley's house before he reached Montgomery Castle. In view of the lack of any evidence at all that he came to Montgomery from the north, it seems at least as plausible that, coming to Wigmore on the way to Montgomery from the south, and stopping for a visit with Harley, Donne learned that the household at Wigmore could not support such a visit. Then passing on to Herbert's house, he wrote back to Wigmore expressing his concern about Harley's health and his regret at having missed a visit, referring to Herbert (with what is more likely to be pointed humor than accusatory resentment) as "thys Noble gentleman, who refuses mee not in hys house". ${ }^{31}$ Donne does not mention any further

31. Philip Herbert, first Earl of Montgomery and Edward Herbert's cousin, had owned Montgomery Castle since King James gave it to him in 1607. It had come into the king's possession as a result of the death of Edward's father and Edward's wardship. Philip Herbert sold it to Edward for $£ 500$ in July 1613, but Edward 
intention to visit or revisit Wigmore, and evidently did not after this letter proceed to do so, because he seems in fact to have joined Goodere at Polesworth by Tuesday, 13 April, whence he wrote to his friend George Garrard in London that he and Goodere were planning to be back in the city by Saturday, 17 April $(1651,285)$.

The biographical and historical data supplied here, suggesting how Donne might have made his journey from London by way of Bristol to Montgomery Castle in the spring of 1613, support the bibliographical conjectures of Croft, Thomson/McKitterick, and Barker that the headings of P2 and PT2 are not (as Gardner maintained) Nathaniel Rich's fancies, or faulty recollections of some earlier heading he might have seen attached to Goodf, but instead record actual details of the journey that inspired it. These facts are grounds to admit the possibility that Donne's 1613 itinerary from London to Montgomery and back to London was the one illustrated in Figure 2 and implied in the headings of P2 and PT2.

\section{The Canonical Goodf and the Versions in Rich's Hand}

Goodf in the 1633 edition or the manuscript Groups differs from the poem recorded in P2 and PT2 not only in some wording but, significantly, in the logic of its argument. As noted above, the major difference turns on the fact that witnessing the crucifixion is imagined unreservedly throughout as a present possibility precluded only by the direction of the speaker's journey. In the Goodf of 1633 and the manuscript Groups, the speaker's reluctance to pursue whatever "Pleasure or businesse" (7) is distracting him is conveyed by his being "carryed towards the West / This day" as his "Soules forme bends toward the East" (9-10). ${ }^{32}$ Particularly noticeable in contrast to the comparable lines in P2 and PT2 is the speaker's present tense in daring to be almost "glad, I do not see / That spectacle of too much weight for mee" (15-6), and then, in four more lines (compared to P2) and two more (compared to PT2), expanding on the hazards of such a spectacle:

Who sees Gods face, that is selfe life, must dye;

What a death were it then to see God dye?

It made his owne Lieutenant Nature shrinke,

It made his footstoole crack, and the Sunne winke. (17-20)

through a family agreement had been living in it since at least 1605, probably even earlier (Pailin 2004).

32. Quotations from the 42-line Goodf follow the second Oxford edition (GARDNER 1978, 30-1). 
Throughout, the reason the speaker of the manuscript Groups' version of Goodf does not "see" the crucifixion is only because he is riding in the wrong direction.

Accordingly, the lines that begin to effect the poem's conclusion in its 42-line form are likewise more straightforward:

Though these things, as I ride, be from mine eye,

They'are present yet unto my memory, [. . .]. (33-4)

Here yet, in its position as the stressed syllable of the second foot of the line that follows a though-clause (rather than as the first syllable in the first foot, as in P2 and PT2, following a declarative sentence) sheds any overtones of a conjunctive adverb ("Yett" or "Yet" in 1.15 of P2 and PT2, in the OED's formulation [yet, $a d v$. (and adj.) and conj., III.9.a], used to "introduce[e] an additional fact or circumstance which is adverse to, or the contrary of what would naturally be expected from, that just mentioned"). It carries primarily the sense of still, always, nonetheless. In other words, in the 42-line poem, the speaker does not suddenly realize he can exercise his memory and recall the Biblical event. Rather, he takes comfort in an assured assertion that, as he pursues, as he must, "Pleasure or businesse", the faculty of memory has been and will always be available to assist his meditation on that event.

The difference effected by the two positionings of yet assumes greater significance in light of the circumstance that, compared to the shorter versions of P2 and PT2, the 42-line Goodf may, by its length, allude to Donne's age in 1613. Only Robin Robbins has commented on the significance of the poem's length in the manuscript Groups:

D. may have been aware that 1613 was his forty-second year for the months after his birthday. According to, e.g., W. Vaughan, Naturall and Artificial Directions for Health (1600), p. 57, 'A climacterical year is every seventh year'. . ., and in it were seen 'great alterations'. $(2010,567)$

Just as, nearing the age of thirty, in a poem written at another pivotal moment in his life (Metem, dated "16 Augusti 1601"), Donne has the poem's speaker refer to his "six lustres, almost now outwore" (1967b, 28), a luster being a period of five years, so the canonical Goodf, compared to the version of it recorded in PT2, reaches its climacterical length of forty-two lines by the addition of "Who sees Gods face, that is selfe life, must dye; / What a death were it then to see God dye?" - a couplet with a repeated word 
rather than a rhyme. What might have motivated Donne to include this couplet, adjusting the verb tense in the lines that preceded it in order to admit it to a poem that already was essentially complete, is perhaps more to the point and certainly as interesting to contemplate as what Gardner thought, that a copyist who knew the poem not quite by heart had left the couplet out.

The difference made by the present-tense of "almost glad, I do not see" leading to the "Who sees Gods face" couplet is remarkable. ${ }^{33}$ Daring to be almost glad on this Good Friday (or, perhaps, any Good Friday) that he does not see the fatally ponderous spectacle of the crucifixion, the speaker is realizing that the alternative to the pleasure or business he is pursuing would in the present moment be his own death. Death, in the final words of Donne's epitaph for his funeral monument in St. Paul's Cathedral, is the moment when "ASPICIT EVM / CVIVS NOMEN EST ORIENS" (Stringer et al. 1995, 193), he beholds Him whose name is the East [the rising]). Goodf concludes, then, with the wish that by the grace of God the speaker's final hour may be a time when the image of his Savior in him will have been restored. In relation to P2 and PT2, the 42-line Goodf seems to have become a poem about the course of the speaker's whole life, up to and including the time of his death. Another way to say this is that in the forms it takes in P2 and PT2, Goodf seems to have been an occasional poem, inspired by the particular circumstance of a journey the speaker, identified in B13 as "Dun goeinge from $\mathrm{S}^{\mathrm{r}} \mathrm{H}$ : G: on good Friday", is represented as taking on a particular day from one particular place to another. At this point, this same heading suggests, it may have been a poem that Donne used in something like the way he might have written a letter, sending Sir Henry Goodere "back this Meditacon, on the Waye".

While the heading of the poem in B13 uses the same word, meditation, to describe the poem that appears in the headings of P2 and PT2, the text of the poem in B13 is closer to the manuscript Groups' version of the poem than it is to P2 and PT2. This suggests that Donne may have produced something like the Groups' version of the poem in the course of the 1613 journey. B13's variants from that text, however, make it very likely that the poem was altered considerably by scribal mistranscription from the form it might have had if, in fact, it was sent in something like Groups' version of

33. Besides P2 and PT2, two other manuscripts have the past-tense "did not see" in line 15, in one of which, H6, it is corrected to "doe not see". The other is C9. Both $\mathrm{H} 6$ and $\mathrm{C} 9$ share other readings with P2 and PT2, though they are not, in those cases, the only ones to do so. 
its text to Goodere under the heading it bears in B13. Not only are three lines omitted, as mentioned above, but B13 reads uniquely "fall" for "face" in line 17 and "wretched" for "miserable" in line 30.34 These possibilities of scribal error, in turn, raise doubts about the accuracy of the B13 heading.

That Donne would have shared some version of this poem with Goodere soon after composing it, however, is certainly likely. In framing it as a meditation in contrast to the pursuit of pleasure or business, Donne returns for the duration of the poem to a situation he rejected as a course of life in a letter to Goodere five years earlier:

But for me, if I were able to husband all my time so thriftily, as not onely not to wound my soul in any minute by actuall sinne, but not to rob and cousen her by giving any part to pleasure or businesse, but bestow it all upon her in meditation, yet even in that I should wound her more, and contract another guiltinesse. $(1651,48-9)$

In the whole of this letter, Donne writes at some length about necessity of "do[ing] something" and the difficulties and hazards he underwent as a younger man choosing "an occupation, and a course which I thought I entred well into, when I submitted my self to such a service, as I thought might imployed [sic] those poor advantages, which I had" (1651, 51). It is pleasant to think of Goodere preserving the letter out of affection for and admiration of his friend; but there is also evidence that Goodere valued its reflections for more personal reasons. In 1619, he extracted from it whole sentences as if they were his own in a letter he wrote to the Duke of Buckingham (Johnson 1948, 41-2). ${ }^{35}$ Clearly of continuing mutual interest were questions of what course to pursue in the world and of the practical and spiritual hazards attending all the choices available to men striving (again using Donne's words from the 1608 letter) to "be so incorporated into the body of the world, that they contribute something to the sustentation of the whole" $(1651,51)$.

This connection between Goodf and the 1608 letter (in which Donne presumes that Goodere would sympathize with his weekly impulse,

34. According to Peter Beal, the B11 version of Goodf, among the Conway Papers, is in Goodere's hand. In B11, the poem has no heading; but it appears less flawed than B13. It includes the lines missing from B13, and reads "Gods face" and "miserable" in lines 17 and 30. See the fuller discussion of the relationship between Goodf and Donne's correspondence with Goodere in Sмітн 2014, 248-50.

35. Note other echoes of the letter in Goodf, the "planetary and erratic fortune" (Donne 1651, 52) and the preoccupation with death. 
prompted by his habit of writing every Tuesday to Goodere, to reflect on "what I have done in the last watch, or would do in the next" $[1651,48]$ ) reinforces the impression that on the 1613 journey Donne was contemplating if not seeking advice and support for a momentous vocational decision. It is, however, also this connection between the poem and the earlier letter that should admonish us not to simplify the relationship between the religious cast of the poem and the fact that some time after returning from this journey Donne wrote to his noble friend James Lord Hay, enclosing for delivery his letter to Robert Carr, Viscount Rochester, with its striking proposal "to make my Profession Divinitie". ${ }^{36}$ Goodf, as the headings in P2, PT2, and B13 specify, is a meditation; and the meditation, inspired by a westward journey on Good Friday, reflects on the reality that all human activity, including, Donne would realize, even the activity of the ministry, is a distraction from devotion. With respect to that reality, Donne writing that letter to Goodere in 1608 has a lively sense that no course of action can be purely sinful or purely good:

Two of the most precious things which God hath afforded us here, for the agony and exercise of our sense and spirit, which are a thirst and inhiation after the next life, and a frequency of prayer and meditation in this, are often envenomed, and putrefied, and stray into a corrupt disease: for as God doth thus occasion, and positively concurre to evill, that when a man is purposed to do a great sin, God infuses some good thoughts which make him choose a lesse sin, or leave out some circumstance which aggravated that; so the devill doth not only suffer but provoke us to some things naturally good, upon condition that we shall omit some other more necessary and more obligatory. And this is his greatest subtilty; because herein we have the deceitfull comfort of having done well, and can very hardly spie our errour because it is but an insensible omission, and no accusing act. (1651, 49-50)

In accordance with this sentiment, the speaker of Goodf does not reverse course and seek "the deceitfull comfort of having done well"; he persists in the course dictated by the "first mover" of his soul, "Pleasure or businesse".

In P2 and PT2, that persistence can be put down to the particular shortcomings of the poem's speaker. In the form Goodf has in P2, the speaker's

36. Donne's letter to Rochester is in A Collection of Letters made by Sr Tobie Mathews $K t$, where it is followed by the letter to Hay that enclosed it (Matthew and Donne, JR. 1660, 319-22). 
meditation on the direction of his journey is resolved by the poem's closing prayer that it be used by God as an opportunity for correction. That final prayer rationalizes the poem's earlier lines:

Yett am I allmost glad, I did not see

That spectacle, of too much weight for me!

Could I behould those hands that spann the Poles,

And tune all Sphæres at once, peir'ced through $\mathrm{w}^{\text {th }}$ holes?

In PT2, the sense of the sight the speaker is spared is deepened by the vivid recollection of scriptural details, but its expression is essentially the same:

Yet am I almost glad I did not see

That Spectacle of too much waight for me

It made his owne Leiutenant Nature shrinke

It made his footestoole crack the Sunn to winke!

Could I behold those hands that span the Poles

And tune all Sphæres, at once board through $\mathrm{w}^{\text {th }}$ Holes?

Both versions of the poem represent a speaker justifying his westward journey as an analog to his distance in time from the historical moment of the crucifixion.

In the 42-line version, however, the logic of the speaker's persistence in the direction of his journey is that he is a mortal being:

Yet dare l'almost be glad, I do not see

That spectacle of too much weight for mee.

Who sees Gods face, that is self life, must dye;

What a death were it then to see God dye?

It made his owne Lieutenant Nature shrinke,

It made his footstoole crack, and the Sunne winke.

Could I behold those hands which span the Poles,

And tune all spheares at once, pierc'd with those holes?

P2 and PT2 highlight the significance of the die-die couplet and the present tense of dare and do. In contrast to the speaker of P2/PT2, the speaker of the 42-line poem realizes that he has no choice but to pursue pleasure and business until he dies. He can only trust that God's grace will find in time some means to restore God's image in him for that final reckoning. 
The 42-line Goodf is a more settled poem than the versions recorded in P2 and PT2. If that settled condition is its glory in the eyes of its readers and editors, it is nonetheless the case that the versions of P2 and PT2 are a path to registering and appreciating that composure; and the possibility that these versions originated, in some way, in Rich's having seen or heard a version of the poem that was not yet in the form Donne eventually resolved on makes the progress of the poem from its appearance in P2 and PT2 to the full form and extent of forty-two lines something that readers who would appreciate Goodf should not ignore.

Colgate University Bentley University 


\section{Appendix A. P2 (see page 85) (Beal, Index, DnJ 1430; in private hands)}

meditation vpon a Good friday, ryding from London towards Exceter, westward

Lett mans soule be a Sphere, and then in this

The'Intelligence that mooues,: Deuotion is:

And as the lesser Sphæres, by beeing growne

Subiect to forreyne motion, loose theyr owne,

And beeing thereby whyrled euery day,

Scarce in a yeare, theyr naturall forme obey

Pleasure, and Business, So, our soules admitt

For theyr first mouer, and are whyrld by it:

Hence is'it that I trauayle vnto the West

This day, when my Soules forme tends vnto the East.

There should I see a Sun by risinge, sett,

And by his settinge endless day begett,

But that Christ on this day did rise and fall,

Synn had eternally benighted all:

Yett am I allmost glad, I did not see

That spectacle, of too much weight for me!

Could I behould those hands that spann the Poles,

And tune all Sphæres at once, peir'ced through $\mathrm{w}^{\text {th }}$ holes?

Could I behould that endless height that is

Zenith to vs, and our Antipodes

Humbled beneath vs? and that bloud that is

The seate of all our Soules (if not of his)

Make durt of dust? or that flesh which was worne

By God for his Apparrell, rent and torne?

Or if on these things I could looke, durst I

Vppon his miserable Mother cast myne eye,

Who was Gods Partner, \& furnished thus

Halfe that Sacrifice that ransommed vs?

Theise things as thus I ryde, are from myne Eye,

Yett are they present to my memory:

That lookes on them and thou lookest on me,

Sweet Sauiour as thou hangst vppon the Tree.

I turne my back to thee, but to receaue

Correction till thy mercye bydd thee leaue.

Oh thinke me worth thyne Anger, punish me,

Scoure of my rust, \& my deformitye,

Renew thyne Image in me by thy Grace

That thou mayest know me, and I'will turne my face. 


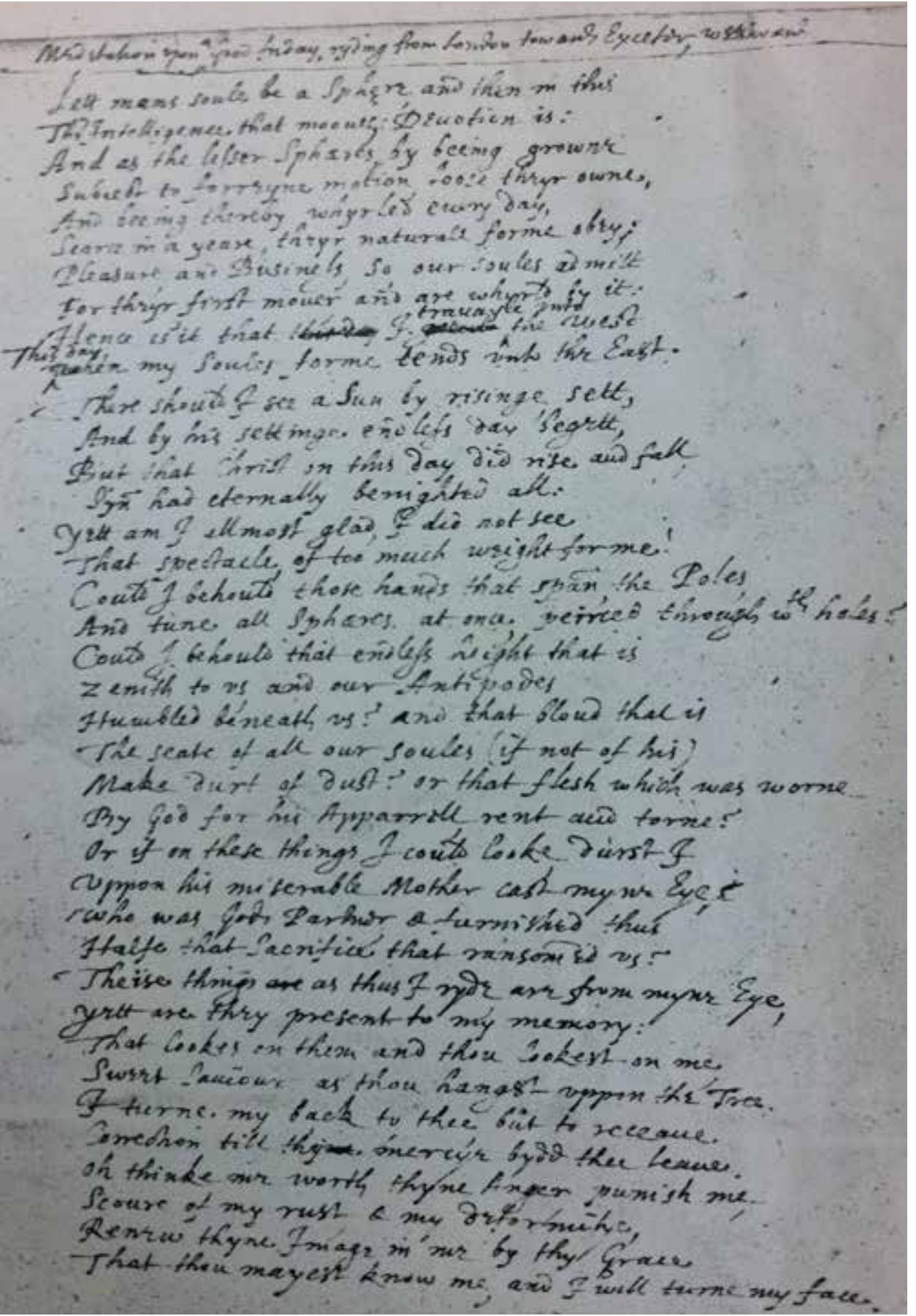




\section{Appendix B. PT2 (see page 87) (Beal, Index, DnJ 1431, in Robert Taylor Collection of the Princeton University Library)}

Meditation on a good friday ridinge from London into $y^{\mathrm{e}}$ West Countrey.

Lett Mans Soule be a Sphære, and then in this

The Intelligence that mooues, Deuotion 'is.

And as the lower Sphæres by beeing growne

Subiect to forreyne motion loose theyr owne.

And beeing by it hurled euery day:

Scarce in a yeare theyr naturall forme obey

Pleasure and Business so our Soules admitt

For theyr first Moouer, and are whirld by it.

Hence it is I trauayle towards the West

This day, when my soules Forme tends vnto $y^{\mathrm{e}}$ East

There should I see a Sun by risinge sett

And by his settinge endless day begett.

But that Christ on the Cross did rise and fall

Synn had eternally benighted all:

Yet am I almost glad I did not see

That Spectacle of too much waight for me

It made his owne Leiutenant Nature shrinke

It made his footestoole crack the Sunn to winke!

Could I behold those hands that span the Poles

And tune all Sphæres, at once board through $\mathrm{w}^{\text {th }}$ Holes?

Could I behold that endless Height that is

Zenith to vs and our Antipodes

Humbled beneath vs? or that Bloud that is

The seate of all our Soules if not of his

Make dirt of dust? or that flesh $w^{\text {ch }}$ was worne

By God for his Apparrell rent and torne?

And if on these I durst not looke, dare I

Vppon his miserable Mother cast myne Eye

Who was Gods Partner and furnished thus

Halfe of $y^{t}$ Sacrifice that ransommed vs?

These thinges as thus I ryde are from myne Eye

Yett are they present to my Memorye.

That lookes on them, and thou lookest towards me

Deare Sauiour as thou hangst vppon that Tree:

I turne my Back to thee, but to receaue

Correction, till thy mercye bidd the leaue

Oh thinke me worth thyne Anger, punishe me

Scoure of my rust and my deformitie

Renew thyne Image in me by thy Grace

That thou mayest know me, and I'will turne my face. 


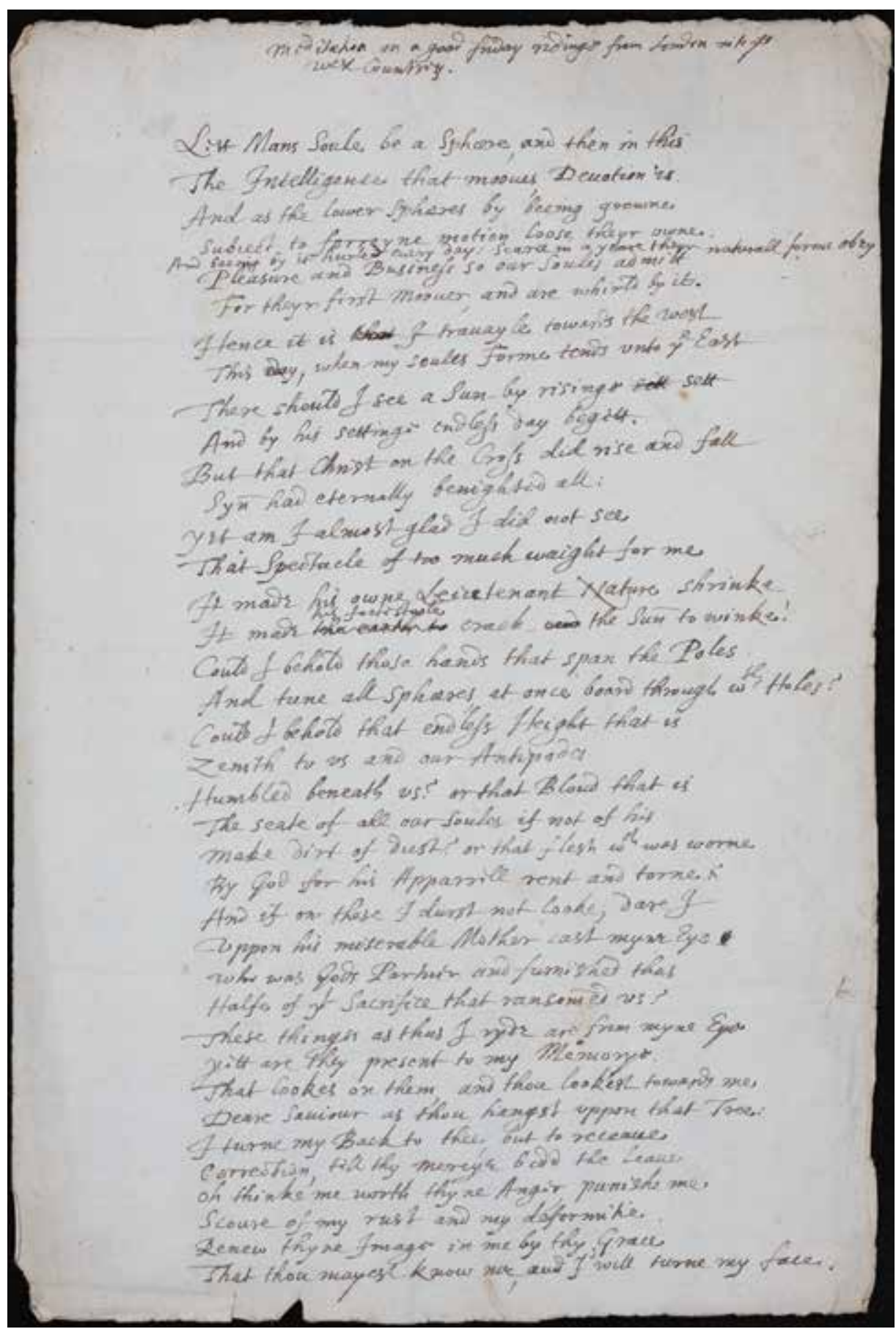

Appendix B 
88 | Textual Cultures 8.2 (2013)

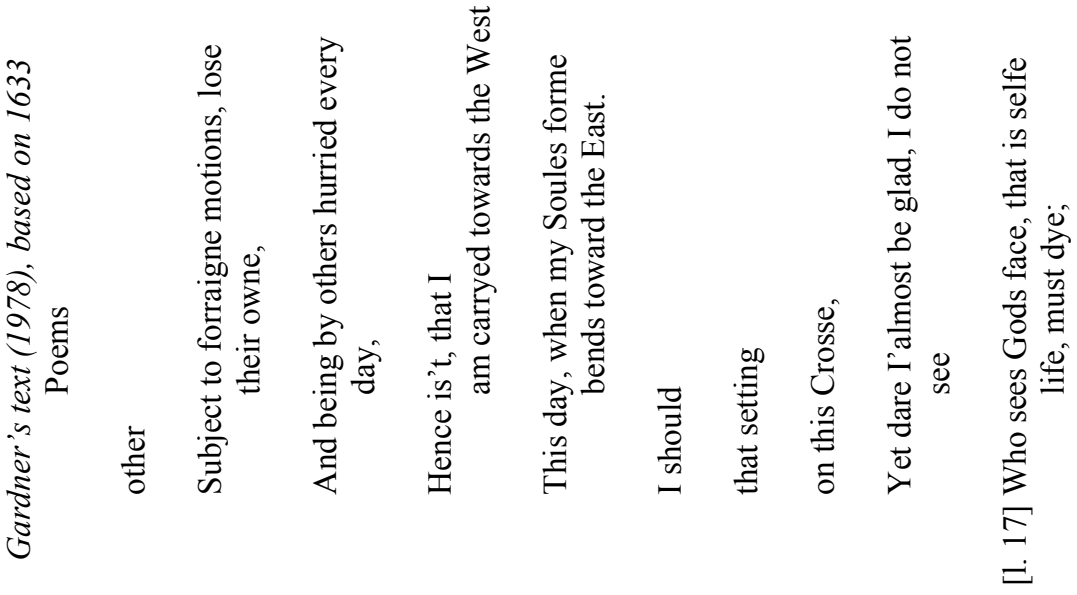

อิ

글

모ำ

苗

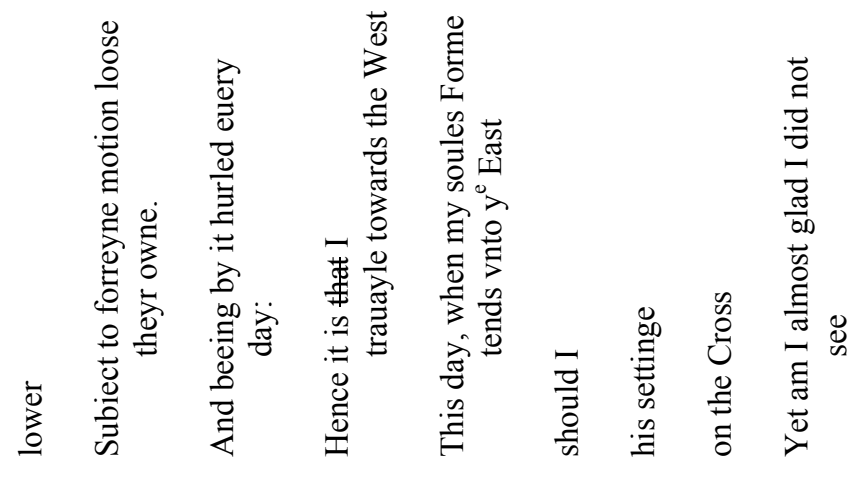

$\stackrel{8}{\Xi}$

.

ฮั

营

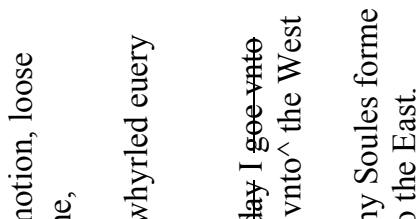

$\stackrel{N}{a}$

$\infty$

乞

高 尺

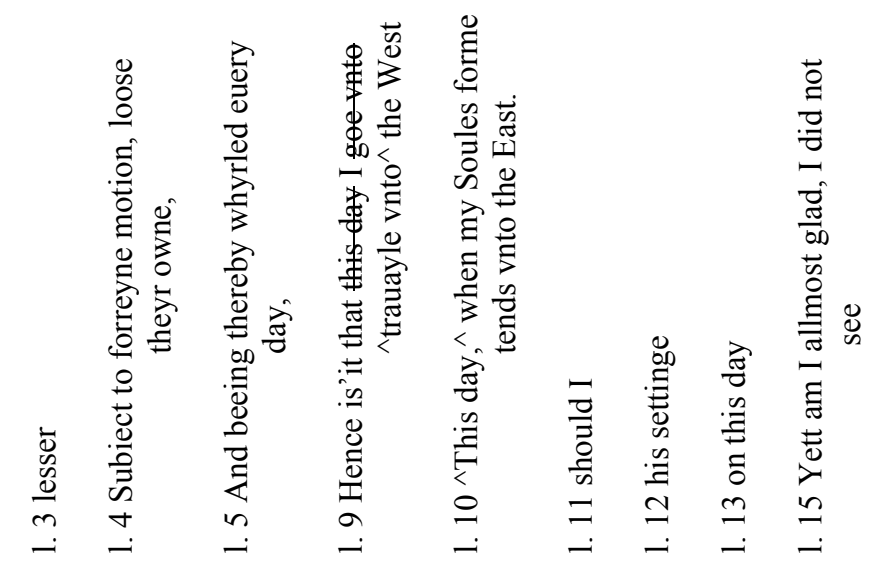




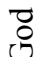

递

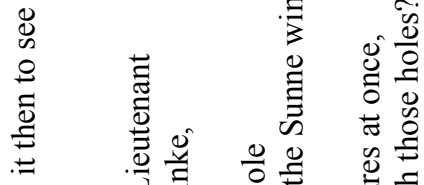

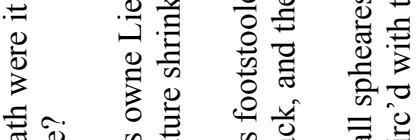

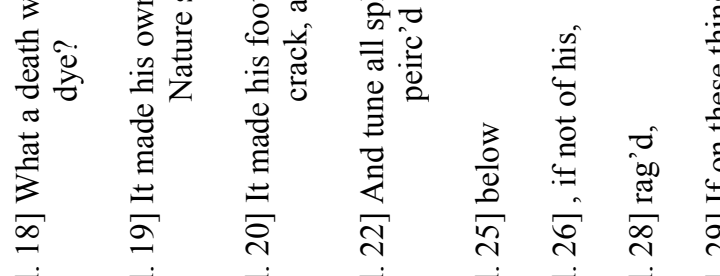

$\dot{\vec{E} \dot{E}}$

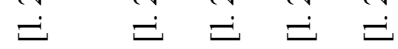

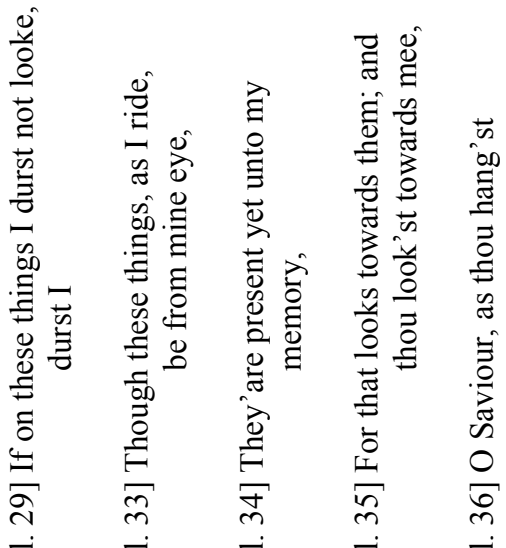

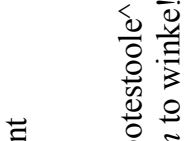

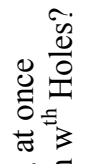

ㅎํㅇ

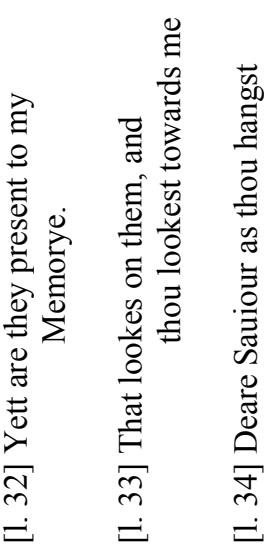

$\dot{\perp} \dot{2}$

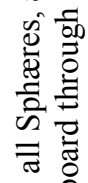

。ำ

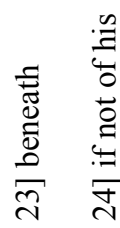

总䓢

要

要

妾

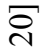

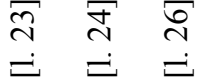

$\frac{\tilde{s}}{8}$

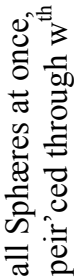

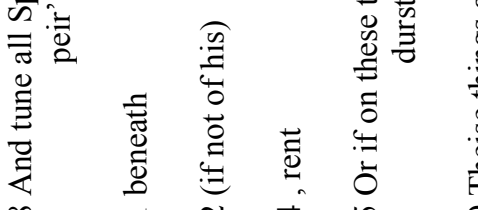

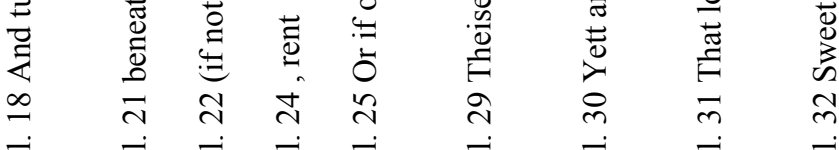


90 | Textual Cultures 8.2 (2013)
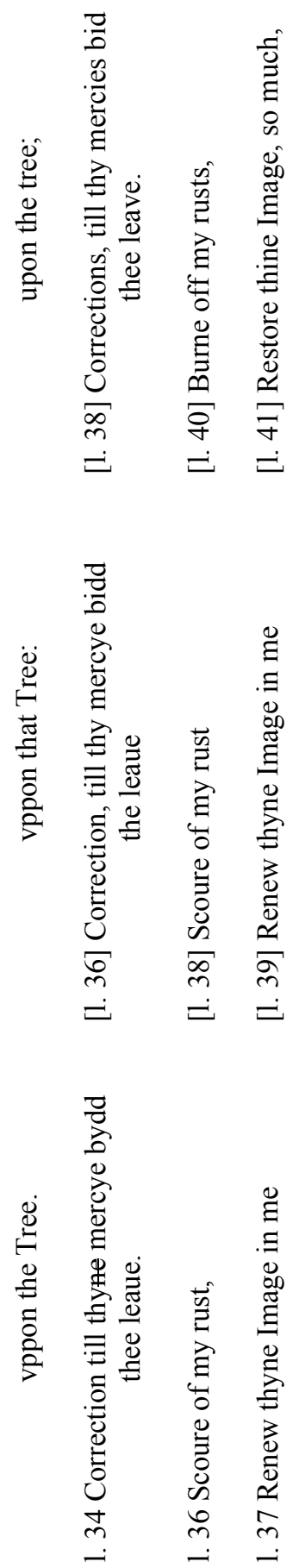


\section{Appendix D. Manuscript Headings for Goodf}

Group I:

C2, C8, O20, SP1 Goodfryday. 1613. Ridinge towards Wales

$\mathrm{B} 32$

Goodf[ ]day 1613. Riding to $\mathrm{S}^{\mathrm{r}}$ Edward Harber in wales

Group II:

DT1, H4, CT1,

B7, WN1, SA1

Good friday / Made as I was Rideing westward, that daye

Group III:

B46

Good Fryday: 1613

H6, C9

Good ffryday. 1613 Riding towards Wales

Group III-Associated:

H5

B13

$\mathrm{H} 3$

$\mathrm{H} 7$

H8

$\mathrm{HH} 1$

Unclassified:

B11

$\mathrm{C} 1$

$\mathrm{P} 2$

PT2

\author{
A Meditation Vpon Good ffriday. / 1613. \\ $\mathrm{M}^{\mathrm{r}}$. I: Dun goeinge from $\mathrm{S}^{\mathrm{r}} \mathrm{H}$ : G: on / good friday \\ sent him back this / Meditacon, on the Waye.| \\ Goodfriday 1613.| st. ms. 360 \\ Good Fryday \\ GOOD FRIDAY. I.D. \\ Good Fryday
}

[omitted]

[omitted]

meditation vpon $>\% \mathrm{Va}<$ Good friday, ryding from London towards Exceter, westward

Meditation on a good friday ridinge from London into $y^{\mathrm{e}} /$ West Countrey. 


\section{Works Cited}

\section{Manuscripts of Goodf (with Donne Variorum sigla):}

Aberystwyth, National Library of Wales, Dolau Cothi ms. 6748 (WN1).

Cambridge, Cambridge University Library, Add. ms. 29 (C1).

Cambridge, Cambridge University Library, Add. ms. 5778 (c) (C2).

Cambridge, Cambridge University Library, Add. ms. 8467 (C8).

Cambridge, Cambridge University Library, Add. ms. 8468 (C9).

Cambridge, Cambridge University, Trinity College Library, R. 3. 12 (CTI).

Cambridge, MA, Harvard University Library, ms. Eng. 966.1 (H3).

Cambridge, MA, Harvard University Library, ms. Eng. 966.3 (H4).

Cambridge, MA, Harvard University Library, ms. Eng. 966.4 (H5).

Cambridge, MA, Harvard University Library, ms. Eng. 966.5 (H6).

Cambridge, MA, Harvard University Library, ms. Eng. 966.6 (H7).

Cambridge, MA, Harvard University Library, ms. Eng. 966.7 (H8).

Capetown, South African Public Library, Grey 7 a 29 (SA1).

Dublin, Trinity College Library, 877 (DT1).

London, British Library, Add. 18647 (B7).

London, British Library, Add. 23229 (B11).

London, British Library, Add. 25707 (B13).

London, British Library, Harley 4955 (B32).

London, British Library, Stowe 961 (B46).

London, St. Paul's Cathedral Library, 49.B.43 (SP1).

New York, NY, New York Public Library, Berg Collection, Westmoreland ms. (NY3).

Oxford, Bodleian Library, Eng. poet. e.99 (O20).

Princeton, Princeton University, Department of Rare Books and Special Collections, Manuscripts Division, Robert H. Taylor Collection (RTC01, Box 6, F27), Beal Index, DnJ 1431 (PT2).

Private hands, Beal Index, DnJ 1430 (P2).

San Marino, CA, Henry Huntington Library, EL 6893 (HH1).

\section{Other Manuscripts:}

Exeter, Devon Record Office, Cary 4088/1/24.

Exeter, Devon Record Office, Cary 4088/1/25.

Exeter, Devon Record Office, Cary 4088/1/34A.

Huntingdon, Huntingdonshire Archives, Manchester Mss. 58/5.

Kew, The National Archives, PROB 11/129/581.

London, British Library, Add. ms. 46491.

London, British Library, Add. ms. 70001/124 $4^{\mathrm{r}-\mathrm{v}}$.

London, House of Lords Record Office, "Diary of Sir Nathaniel Rich" (formerly in the possession of the Duke of Manchester).

Oxford, Bodleian Library, Eng. poet. d.197. 


\section{Printed Sources}

Alton, R[eginald] E., and P[eter] J. Croft. 1974. "John Donne”. Times Literary Supplement, 1042-3.

BALD, R[obert] C. 1970. John Donne, A Life. Oxford: Oxford University Press.

BArker, Nicolas. 1973. "Donne's 'Letter to the Lady Carey and Mrs. Essex Riche': Text and Facsimile". The Book Collector 22: 487-93.

—. 1974. "Goodfriday 1613': by whose hand?". Times Literary Supplement, 996-7.

Beal, Peter. 1980. Index of Literary Manuscripts, I, 1450-1625, Part I, Andrewes Donne. London: Bowker.

Brayshay, Mark. 1991. "Royal post-horse routes in England and Wales: the evolution of the network in the later sixteenth and early-seventeenth centuries". Journal of Historical Geography 17: 373-9.

- Philip Harrison and Brian Chalk ley. 1998. "Knowledge, nationhood and governance: the speed of the Royal post in early-modern England". Journal of Historical Geography 24: 265-88.

Carter, R. N. 2004. "Rich, Richard, first Baron Rich (1496/7-1567), lord chancellor". Oxford Dictionary of National Biography. DOI:10.1093/ref:odnb/23491.

Carey, John. 1981. John Donne, Life, Mind and Art. Oxford: Oxford University Press.

Chambers, A. B. 1987. “Goodfriday, 1613. Riding Westward': Looking Back”. John Donne Journal 6: 185-201.

Croft, P[eter] J. 1973. Autograph Poetry in the English Language. 2 vols. London: Cassell. . 1970. "268 Donne (John) Contemporary Manuscript of his poem 'Good friday, 1613. Riding Westward,' here entitled 'Meditation on a good friday ridinge from London into y ${ }^{\mathrm{e}}$ West Countrey". Catalogue of Valuable Printed Books, Autograph Letters and Historical Documents [. . .] Tuesday, 23rd June, 1970 [. . . ]. London: Sotheby \& Co.

Digital Donne. The On-line Variorum. DOI: 10.1145/1255175.1255257. http://dx.doi .org/10.1145/1255175.1255257.

Donne, John. 1633. Poems, by J. D. with Elegies on the Authors Death. London: John Marriot.

1651. Letters to Severall Persons of Honour. London: Richard Marriot.

1967a. The Poems of John Donne, edited by John T. Shawcross. Garden City, New York: Doubleday.

1967b. The Satires, Epigrams and Verse Letters, edited by W[esley] Milgate. Oxford: Clarendon Press.

Ga R Dner, Helen, ed. 1952, rev. ed. 1978. John Donne: The Divine Poems. Oxford: Clarendon Press.

Guibbory, Achsah. 2011. "Donne and Apostasy". The Oxford Handbook of John Donne, edited by Jeanne Sh ami, Dennis Flyn , and M. Thomas Hester, 664-77. Oxford: Oxford University Press.

Historical Manuscripts Commission. 1979. Eighth Report of the Royal Commission on Historical Manuscripts, Appendix (Part II). Nendeln/Leichstenstein: Kraus Reprint.

Hodson, Donald. 2000. "The early printed road-books and itineraries of England and Wales”. 2 vols. University of Exeter thesis. 
Hoffm an, Theodore. 1974. "John Donne”. Times Literary Supplement, 1018.

Johnson, Stanley. 1948. "Sir Henry Goodere and Donne's Letters”. Modern Language Notes 63: 38-43. http://dx.doi.org/10.2307/2908641.

Kay, Dennis. 1986. "Poems by Sir Walter Aston, and a Date for the Donne/Goodyer Verse Epistle 'Alternis Vicibus"'. Review of English Studies 37: 198-210. http://dx.doi .org/10.1093/res/XXXVII.146.198.

Keen, Geraldine. 1970. "Expert finds poem in Donne's hand". The Times (London), 5 June: 2.

Lotz-Heumann, Ute. 2004. "Sir George Carey [Cary] (c.1541-1616), lord deputy of Ireland”. Oxford Dictionary of National Biography. DOI:10.1093/ref:odnb/4646. http://dx.doi.org/10.1093/ref:odnb/4646.

Matthew, Toby and John Donne, Jr., eds. 1660. A Collection of Letters made by Sr Tobie Mathews Kt. London: Henry Herringman.

PAGE, William, ed. 1972. A History of the County of Gloucester. Victoria History of the Counties of England. Vol 10. London: Published for the Institute of Historical Research by Oxford University Press.

Pailin, David A. "Herbert, Edward, first Baron Herbert of Cherbury and first Baron Herbert of Castle Island (1582? -1648)". Oxford Dictionary of National Biography. DOI: 10.1093/ref:odnb/13022. http://dx.doi.org/10.1093/ref:odnb/13022.

Pestell, Thomas. 1940. The Poems of Thomas Pestell, ed. Hannah Buchan. Oxford: Blackwell.

Robiins, Robin, ed. 2010. The Complete Poems of John Donne. Harlow: Longman.

Russell, Conrad. 1979. Parliaments and English Politics, 1621-1629. Oxford: Clarendon Press.

Sh Ami, Jeanne. 2011. "Donne's Decision to Take Orders". The Oxford Handbook of John Donne, edited by Jeanne Shami, Dennis Flynn, and M. Thomas Hester, 523-36. Oxford: Oxford University Press.

Smith, Daniel Starza. 2014. John Donne and the Conway Papers: Patronage and Manuscript Circulation in the Early Seventeenth Century. Oxford: Oxford University Press.

Stringer, Gary. 2002. "Discovering Authorial Intention in the Manuscript Sequences of Donne's Holy Sonnets”. Renaissance Papers 2002: 127-39.

- 2011. "The Composition and Dissemination of Donne's Writings". The Oxford Handbook of John Donne, edited by Jeanne SH A mi, Dennis Fly nN, and M. Thomas Hester, 11-25. Oxford: Oxford University Press.

Stringer, Gary et al., eds. 2005. The Variorum Edition of the Poetry of John Donne, Vol. 7.1. Bloomington, IN: Indiana University Press.

Thomson, R[eginald]. S., and David McKiтterick. 1974. "A Donne Discovery". Times Literary Supplement, 930.

—. 1974. “John Donne's Kimbolton Papers”. Times Literary Supplement, 869-73.

TodD, Richard. 2001. "Donne's 'Goodfriday 1613. Riding Westward': The Extant Manuscripts and the Group I Stemma”. John Donne Journal 20: 201-18.

Yerby, George, and Rosemary Sgroi. 2010. "Rich, Nathaniel (c. 1585-1636)". The House of Commons, 1604-1629. Edited by Andrew Thrush and John P. Ferris. 6 vols. Cambridge: Published for the History of Parliament Trust by Cambridge University Press. 